PNNL-19455-SUM

Summary of the

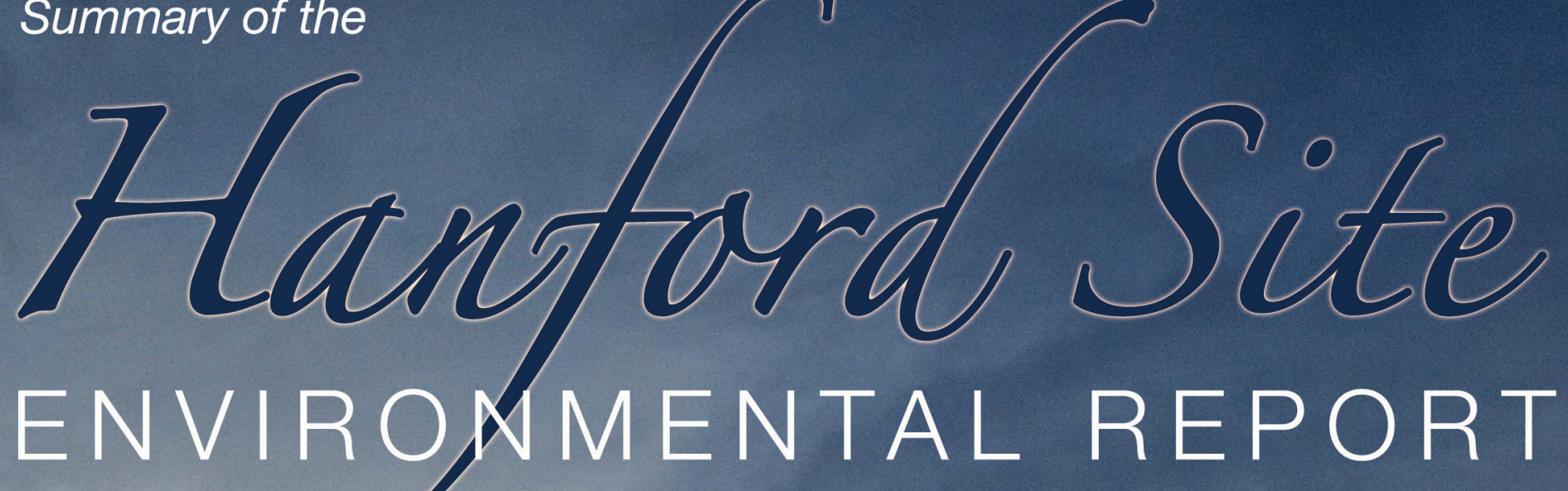




\section{Summary of the}
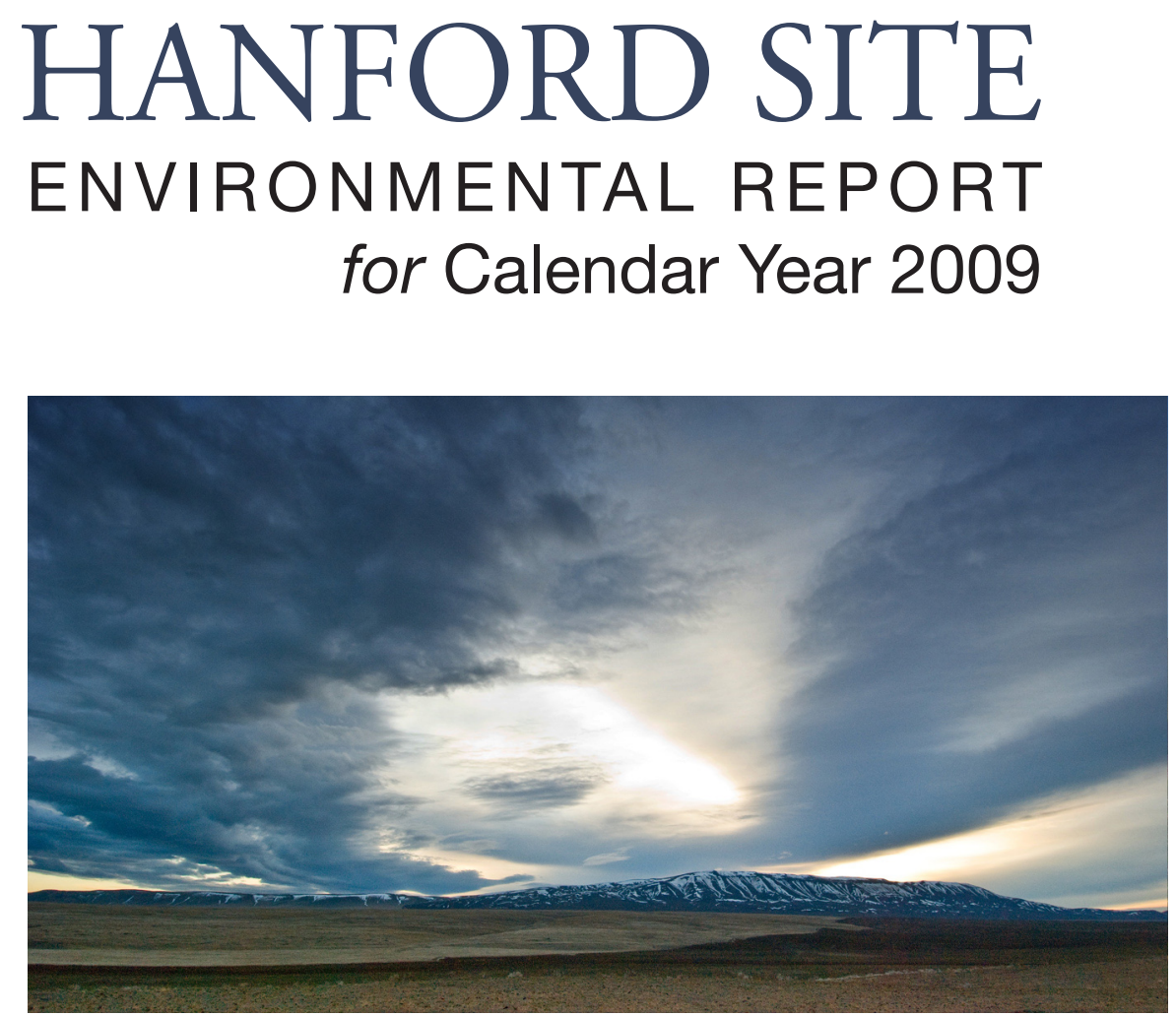

\section{EDITORS \\ JP DUNCAN \\ TM POSTON \\ RL DIRKES}

\section{SEPTEMBER 2010}

Prepared for the U.S. Department of Energy by Pacific Northwest National Laboratory under contract DE-AC05-76RL01830, with contributions from Bechtel National, Inc.; CH2M HILL Plateau Remediation Company; Mission Support Alliance, LLC; Washington Closure Hanford, LLC; and Washington River Protection Solutions LLC

Pacific Northwest National Laboratory Richland, Washington 


\section{DISCLAIMER}

This report was prepared as an account of work sponsored by an agency of the United States Government. Reference herein to any specific commercial product, process, or service by trade name, trademark, manufacturer, or otherwise does not necessarily constitute or imply its endorsement, recommendation, or favoring by the United States Government or any agency thereof, or Battelle Memorial Institute.

\section{COVER}

The cover photo shows the setting winter sun trying to penetrate a thick layer of altocumulus and cirrus clouds, providing a dramatic backdrop for Rattlesnake Mountain. Warming temperatures have melted recent snow, leaving a stark contrast in the foreground. The cover photo is courtesy of $S$ Butner, Pacific Northwest National Laboratory, Richland, Washington. The cover and layout designs are by SB Colson and document layout is by KR Neiderhiser, both of Pacific Northwest National Laboratory, Richland, Washington. All photographs in this report were provided by Pacific Northwest National Laboratory staff, except when otherwise noted. 


\section{CONTENTS}

Introduction 1

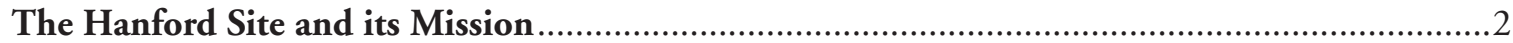

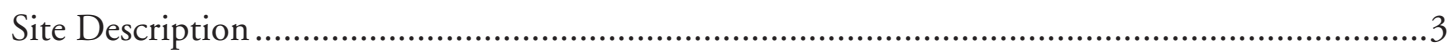

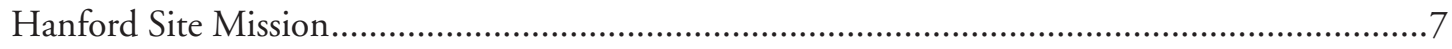

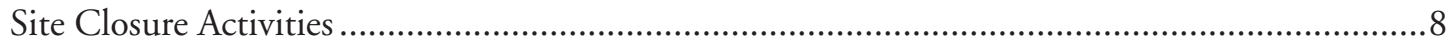

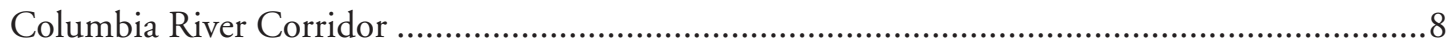

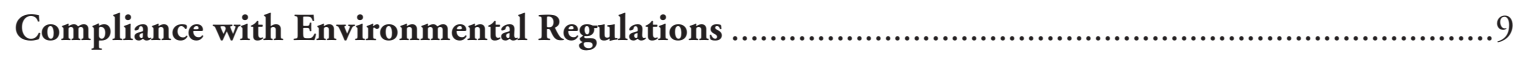

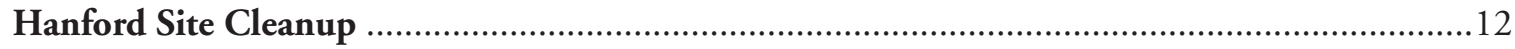

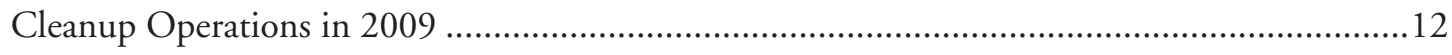

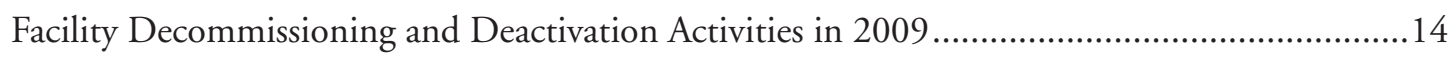

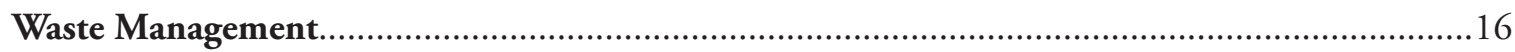

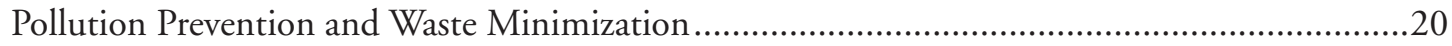

Environmental and Resource Protection Programs .........................................................21

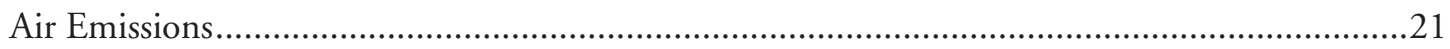

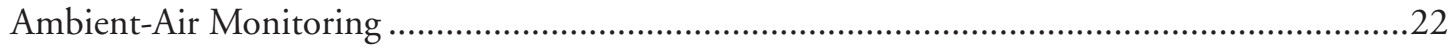

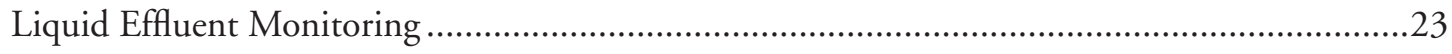

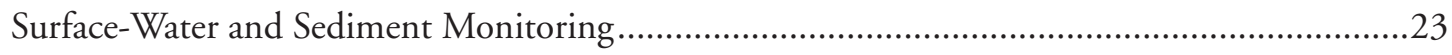

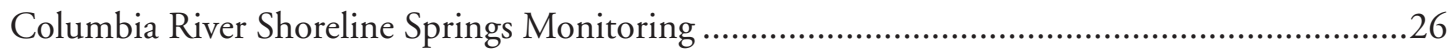

Radiological Monitoring of Hanford Site Drinking Water .....................................................2

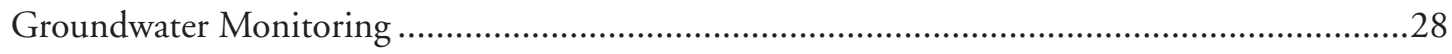




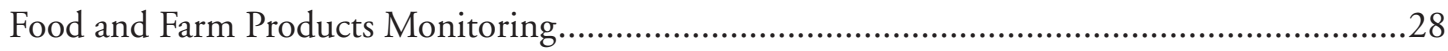

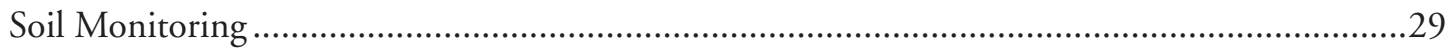

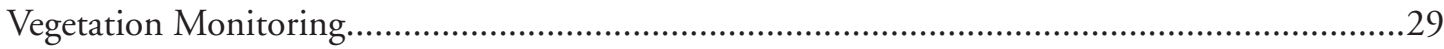

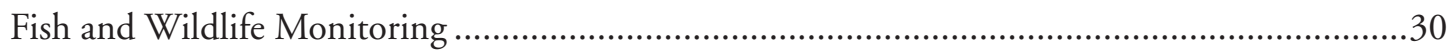

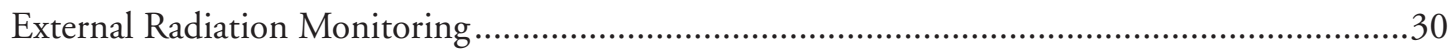

Potential Radiological Doses from 2009 Hanford Site Operations .............................................31

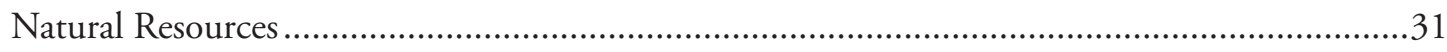

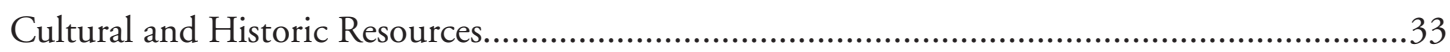

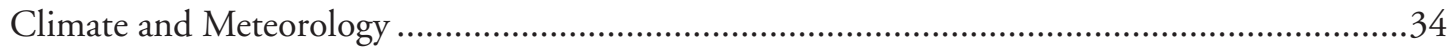

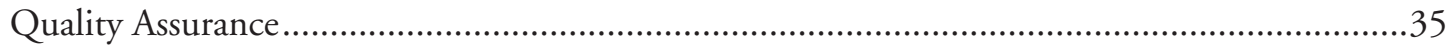




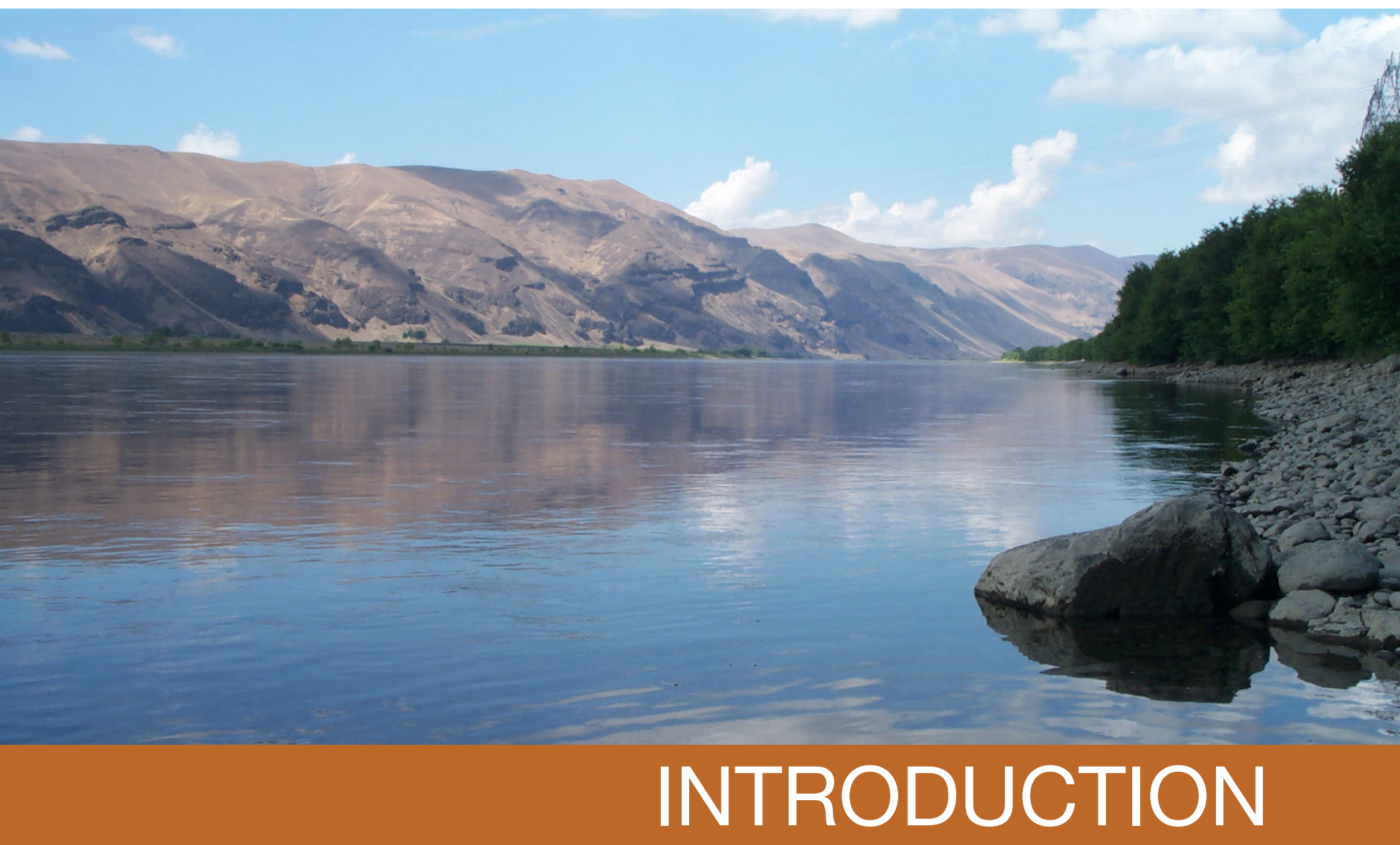

The Columbia River flows eastward through the northern part of the Hanford Site before turning south, forming part of the eastern boundary. Photo courtesy of

This booklet summarizes the Hanford Site Environmental Report for Calendar Kyle Larson. Year 2009. The Hanford Site environmental report, published annually since 1959 , includes information and summary data that provide an overview of activities at the U.S. Department of Energy's (DOE) Hanford Site.

This booklet provides brief descriptions of the Hanford Site and its mission, the status and results of cleanup and facility deactivation and decommissioning activities, environmental monitoring and surveillance programs and activities, and estimated radiological doses to the public and biota from 2009 Hanford Site activities. Readers interested in more detailed information can consult the 2009 Hanford Site environmental report or the technical documents cited and listed in that report. This booklet and the report are available online at http:// hanford-site.pnl.gov/envreport/. 
Today, under the direction of DOE, the Hanford Site is engaged in the world's largest environmental remediation and cleanup project, collaborating with technical, regulatory, cultural, and political groups and representatives.

Non-DOE operations and activities on Hanford Site leased land include commercial power production by Energy Northwest at the Columbia Generating Station and

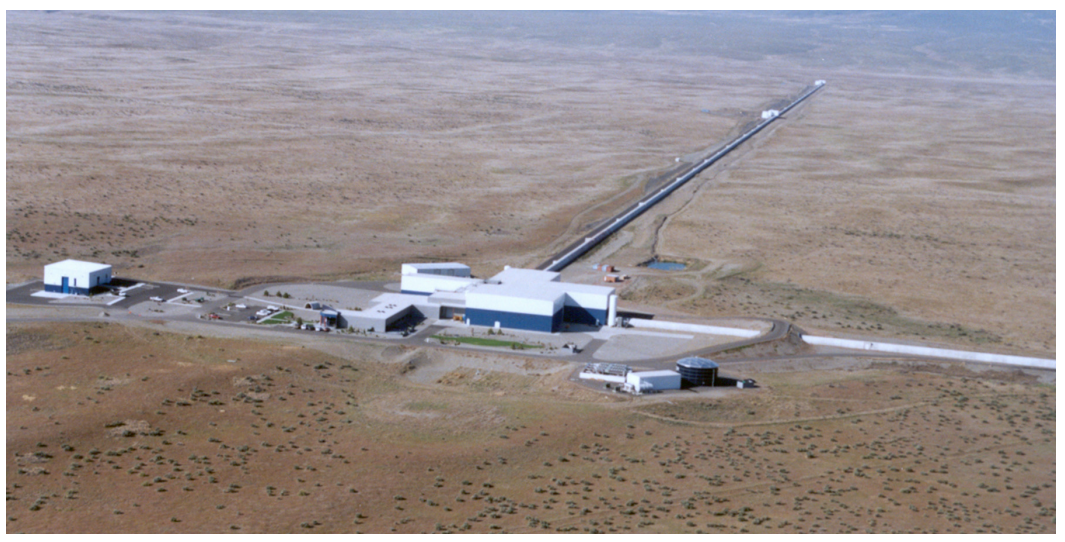

The Laser Interferometer GravitationalWave Observatory is located on Hanford Site leased land. Photo courtesy of LIGO Laboratory. active waste burial site by US Ecology Washington, Inc. The Laser Interfeis jointly operated by the California Institute of Technology and the Massachusetts Institute of Technology with sponsorship by the National Science Foundation.

\section{SITE DESCRIPTION}

The Hanford Site lies within the semi-arid Pasco Basin of the Columbia Plateau in southeastern Washington State. The site, a relatively undeveloped area of shrub-steppe habitat (a drought-resistant, shrub and grassland ecosystem) containing a rich diversity of plant and animal life, occupies an area of approximately 586 square miles located north of the city of Richland, Washington. Public access to much of the site is restricted, and its large land area provides a buffer for the smaller areas on the site that historically were used for production of nuclear materials, waste storage, and waste disposal. The Columbia River flows eastward through the northern part of the Hanford Site and then turns south, forming part of the eastern site boundary.

In June 2000, the Hanford Reach National Monument was formally established on the site by Presidential Proclamation to protect the nation's only unimpounded stretch of the

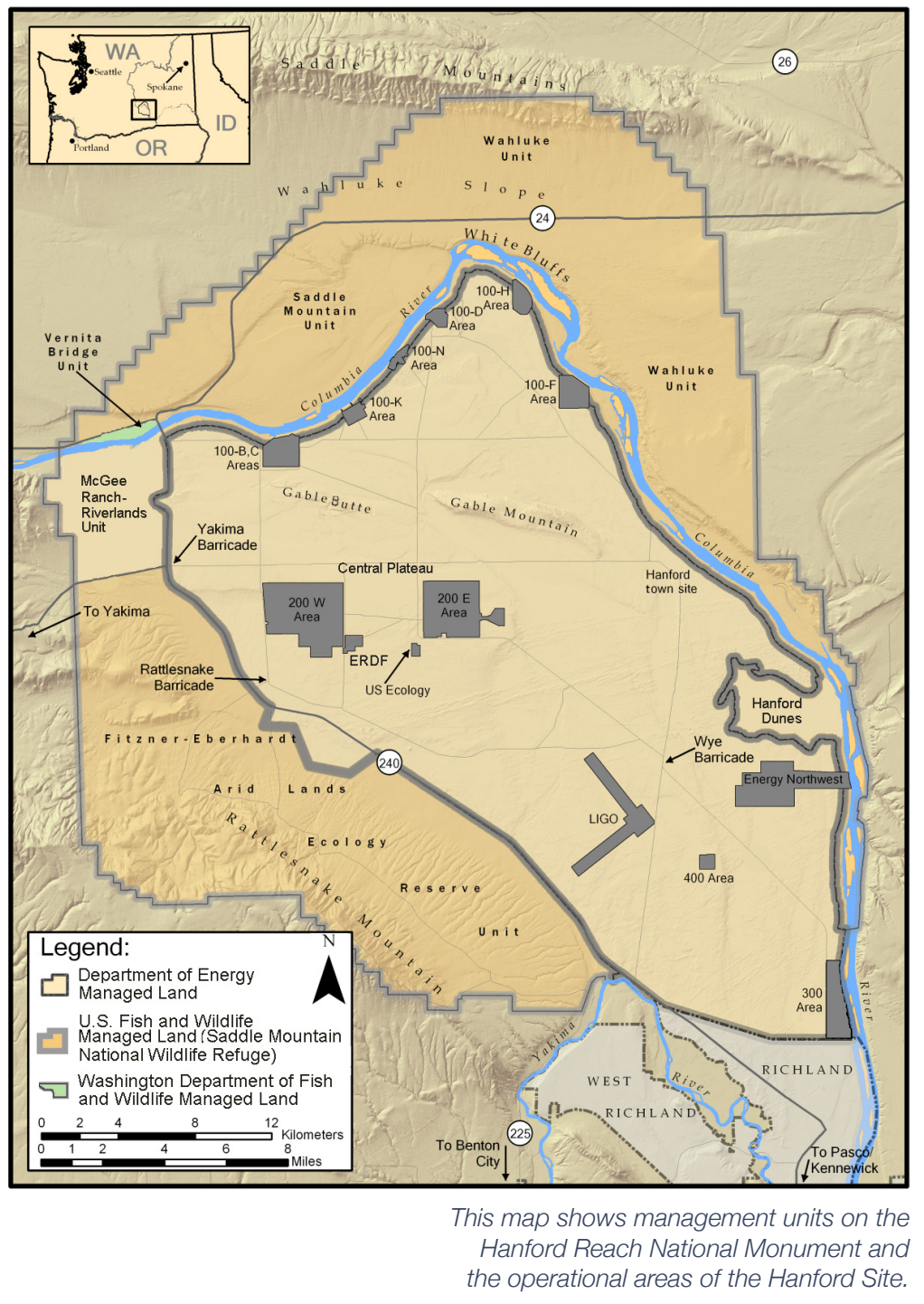




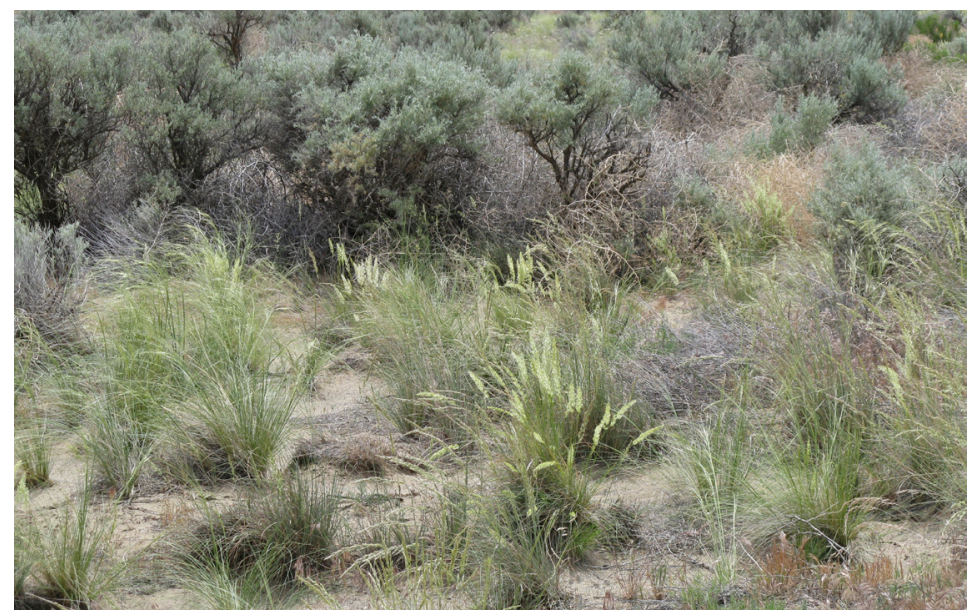

The Hanford Site is a relatively undeveloped area of shrub-steppe (a drought-resistent shrub and grassland ecosystem) containing a rich diversity of plant and animal species. Photo courtesy of Mickie Chamness.

\section{The Hanford Site lies} within the semi-arid

Pasco Basin of the

Columbia Plateau

in southeastern

Washington State.
Columbia River above Bonneville Dam in the United States, as well as the remaining shrub-steppe ecosystem that once blanketed the Columbia River Basin. In 2009, the DOE, U.S. Fish and Wildlife Service, and Washington Department of Fish and Wildlife each managed units of the monument.

The DOE Richland Operations Office and DOE Office of River Protection jointly manage the Hanford Site through several contractors and their subcontractors. The DOE Richland Operations Office manages the cleanup of waste from historical operations, research, and other programs at the Hanford Site. The DOE Office of River Protection manages DOE's largest, most complex environmental cleanup project - retrieval, treatment, and disposal of tank waste at the Hanford Site.

The major DOE operational, research, and administrative areas on and around the Hanford Site include the following:

- 100 Areas - The 100 Areas, consisting of six distinct sites situated along the shore of the Columbia River in the northern portion of the site, were the location of nine nuclear reactors that have since been retired. The 100 Areas occupy approximately 4 square miles.

\section{HANFORD SITE AT A GLANCE}

\section{Location}

Dominant Features

Size

Employees

Mission

Site Management
The U.S. Department of Energy's Hanford Site is located in southeastern Washington State near the city of Richland.

Rattlesnake Mountain on the Fitzner/Eberhardt Arid Lands Ecology Reserve Unit of the Hanford Reach National Monument rises 3,525 feet above sea level, and the Columbia River flows through the northern and eastern part of the site.

The site covers approximately 586 square miles.

DOE and its contractors employed approximately 15,558 workers in 2009.

The Hanford Site mission is to safely clean up and manage the site's facilities and waste, and reduce the size of the site by releasing the land for other uses.

DOE's Richland Operations Office and Office of River Protection jointly manage the central portion of the Hanford Site through several contractors and their subcontractors. DOE, U.S. Fish and Wildlife Service, and Washington Department of Fish and Wildlife each manage units of the Hanford Reach National Monument. 
Located in the 100-B Area is the B Reactor, a National Historic Landmark. It is the world's first industrial-scale nuclear reactor, where the plutonium was produced for the first atomic explosion (the Trinity Test) and the Nagasaki, Japan, atomic bomb. DOE offers scheduled tours of B Reactor.

- 200 Areas - The 200-East and 200-West Areas, occupying an area of approximately 6 square miles, are located on the Central Plateau, approximately 5 and 7 miles, respectively, south and west of the Columbia River. The plateau surface is approximately 328 feet above the level of the Columbia River and about 280 feet above the underlying water table. These areas contain underground waste storage tanks and housed facilities (known as "separations plants") that extracted plutonium from dissolved irradiated fuel. The 200-North Area, now considered part of the 600 Area, is located near Gable Mountain, north of the 200-East and 200-West Areas and approximately 4 to 7.5 miles south of the 100 Areas. Covering approximately 0.1 square mile, the 200-North Area temporarily stored irradiated fuel on railcars.

- 300 Area - The 300 Area is located just north of the city of Richland and covers approximately 0.6 square mile. From the early 1940 s until the advent of the cleanup mission, nuclear fuel fabrication and research and development activities at the Hanford Site were performed in the 300 Area.

- 400 Area - The 400 Area is located northwest of the 300 Area, and covers approximately 0.23 square mile. This area includes the Fast Flux Test Facility, which has not operated since 1992. In June 2009 , the facility was placed in a low-cost, long-term surveillance and maintenance condition. This nuclear reactor was designed and used to test various types of nuclear fuel, produce medical and industrial isotopes, and conduct cooperative international research.

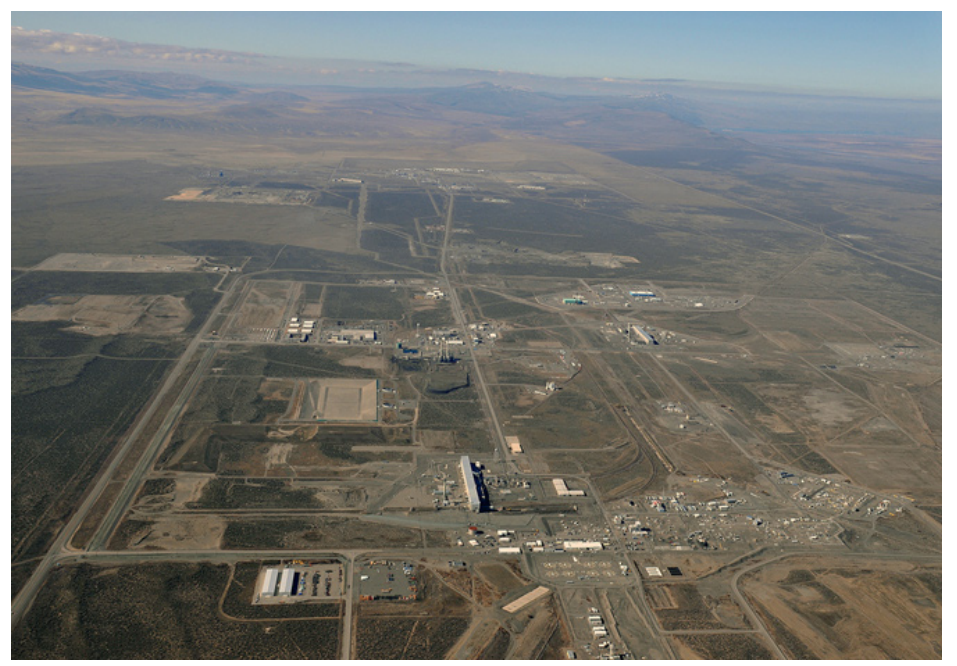

The 200-East and 200-West Areas, located on the Central Plateau, are the location of 177 underground storage tanks. Photo courtesy of the U.S. Department of Energy.

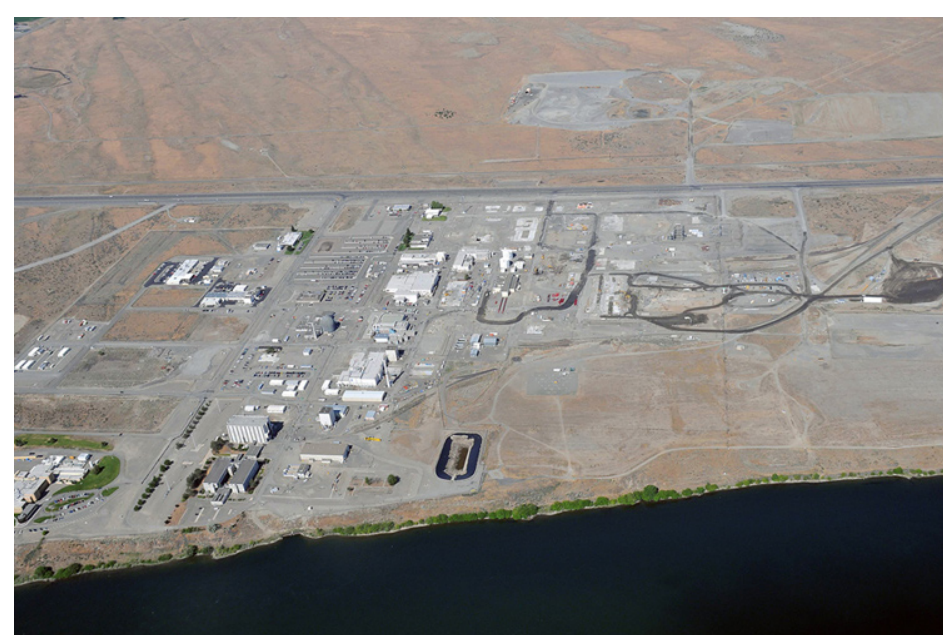

The 300 Area is undergoing active decommissioning; eight facilities and buildings were demolished in 2009. Photo courtesy of the U.S. Department of Energy.

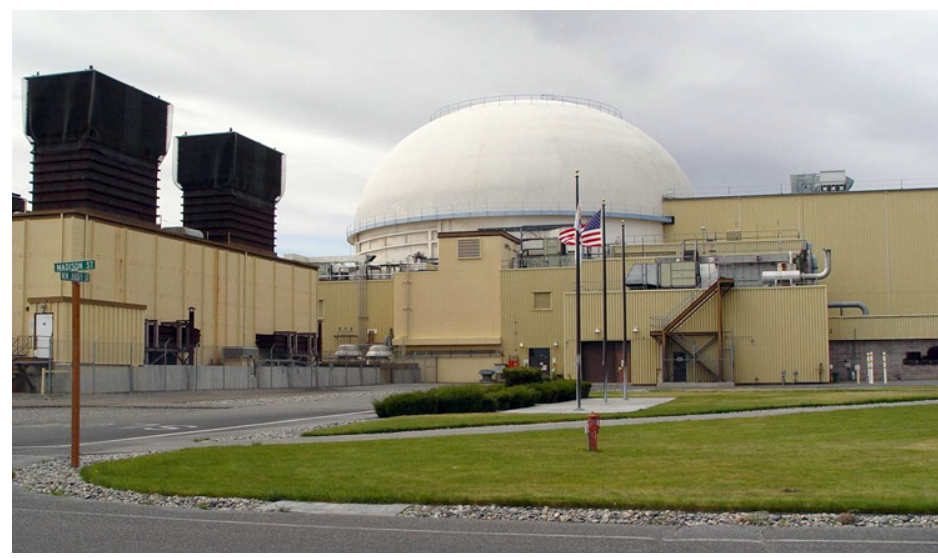

The Fast Flux Test Facility, once an active nuclear test reactor as pictured here, was placed in low-cost, long-term surveillance and maintenance condition in 2009. Photo courtesy of the U.S. Department of Energy. 


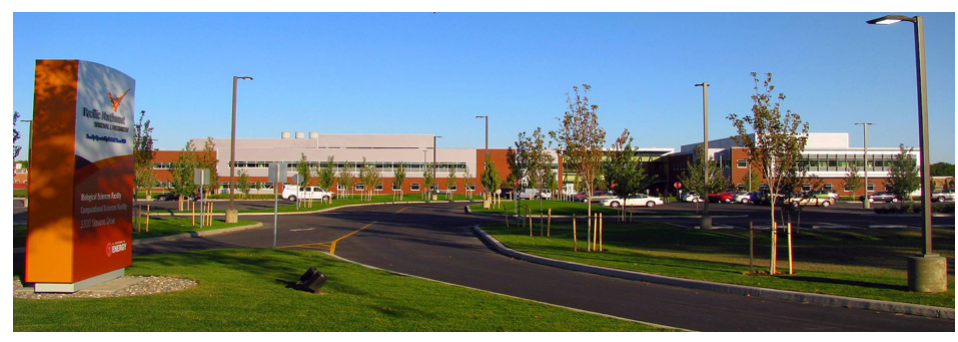

Pacific Northwest National Laboratory's Biological Sciences Facility and the Computational Sciences Facility were dedicated in the fall of 2009, and will enable discoveries in biological, computational, and subsurface science and developments in bioenergy, carbon sequestration, and homeland security.

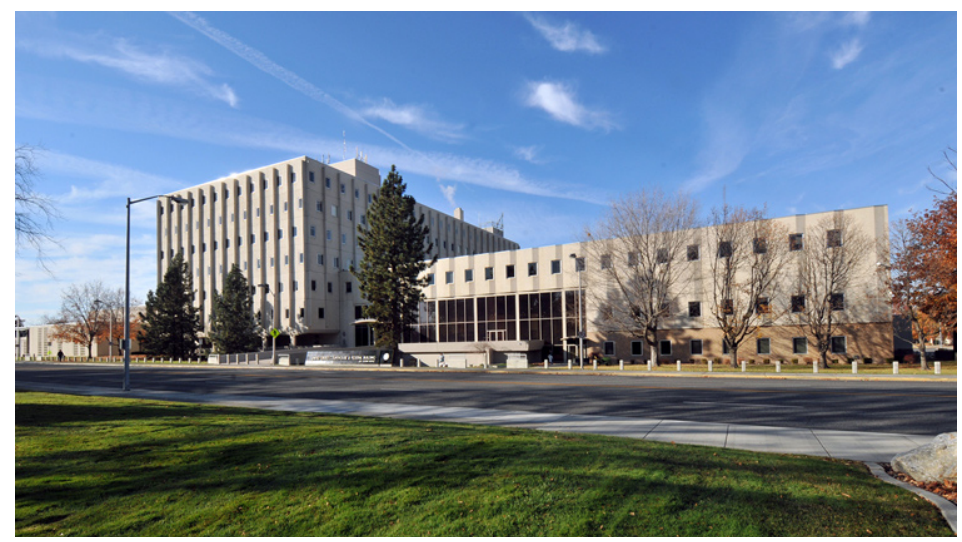

U.S. Department of Energy, Richland Operations Office, located in the Federal Building in the 700 Area. Photo courtesy of the U.S. Department of Energy.

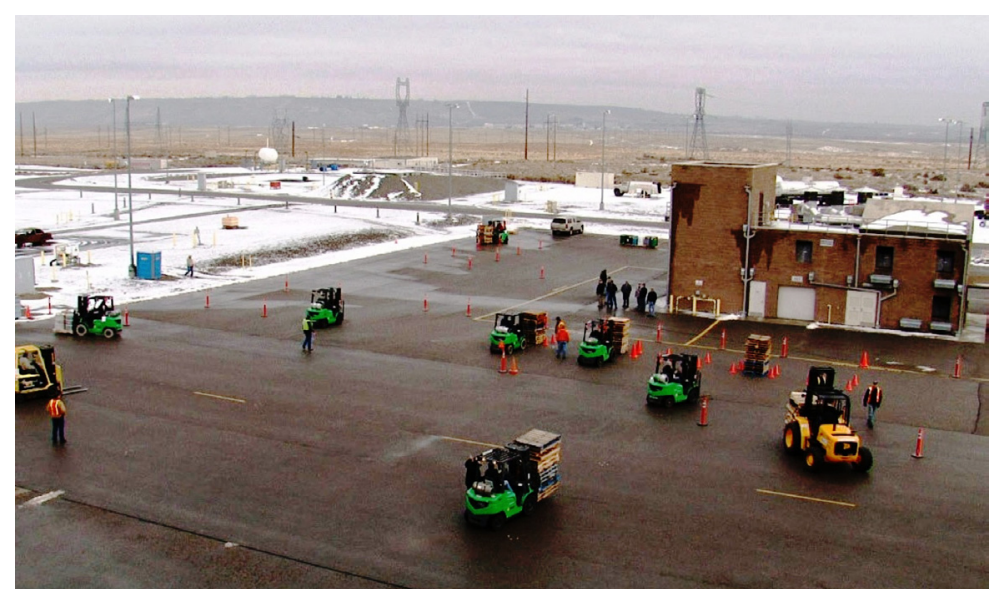

Worker safety and security training is conducted at the Volpentest Hazardous Materials Management and Emergency Response Training and Education Center on the Hanford Site. Photo courtesy of the U.S. Department of Energy.
- 600 Area - The 600 Area includes all of the Hanford Site not occupied by the 100, 200, 300, and 400 Areas.

- Former 1100 Area - The former 1100 Area, covering approximately 1.2 square miles, is located between the 300 Area and the city of Richland. In 1998, this area was transferred to the Port of Benton as part of the DOE Richland Operations Office economic diversification efforts and is no longer part of the Hanford Site. DOE contractors continue to lease facilities in this area.

- Richland North Area (off the site) - This area includes the Environmental Molecular Sciences Laboratory and Pacific Northwest National Laboratory, administered by the Pacific Northwest Site Office of the DOE Office of Science, as well as other DOE and contractor facilities (mostly office buildings) generally located in the northern part of the city of Richland.

- 700 Area (off the site) - The 700 Area includes DOE administrative buildings in the central part of the city of Richland.

\section{- Volpentest Hazardous Materials Manage-} ment and Emergency Response Training and Education Center (also called HAMMER) This worker safety training facility is located on the site near the city of Richland. It consists of an 80-acre main site and a 10,000-acre law enforcement and security training site. The facility, owned by DOE, was managed by Fluor Hanford, Inc. until late August 2009, then subsequently by Mission Support Alliance, LLC. HAMMER is used by site contractors, federal and state agencies, tribal governments, and private industries. 


\section{HANFORD SITE MISSION}

For more than 40 years, Hanford Site facilities were dedicated primarily to the production of plutonium for national defense and management of the resulting waste. In recent years, efforts at the site have focused on developing new waste treatment and disposal technologies, and the characterization and cleanup of contamination left from historical operations. Physical challenges at the Hanford Site include managing or cleaning up millions of gallons of highly radioactive liquid waste in 177 underground storage tanks; 2,300 tons of spent nuclear fuel; 9 tons of plutonium in various forms; approximately 25 million cubic feet of buried or stored solid waste; more than 1,700 former waste disposal sites; and approximately 500 contaminated facilities.

In 2009, DOE's primary mission was environmental remediation and cleanup, including the remediation of contaminated areas and the decontamination and decommissioning of Hanford Site facilities. The Performance Management Plan for the Accelerated Cleanup of the Hanford Site states the cleanup mission includes the following strategies:

- Restore the Columbia River Corridor by accelerating cleanup of Hanford Site sources of radiological and chemical contamination that threaten the air, groundwater, or Columbia River. Most river corridor projects are expected to be complete by 2012 .

- Complete tank waste treatment by 2028 and end the tank waste program by 2033 by accelerating waste retrieval, increasing the capacity of the Hanford Tank Waste Treatment and Immobilization Plant (currently under construction), and continuing the process of closing underground waste storage tanks.

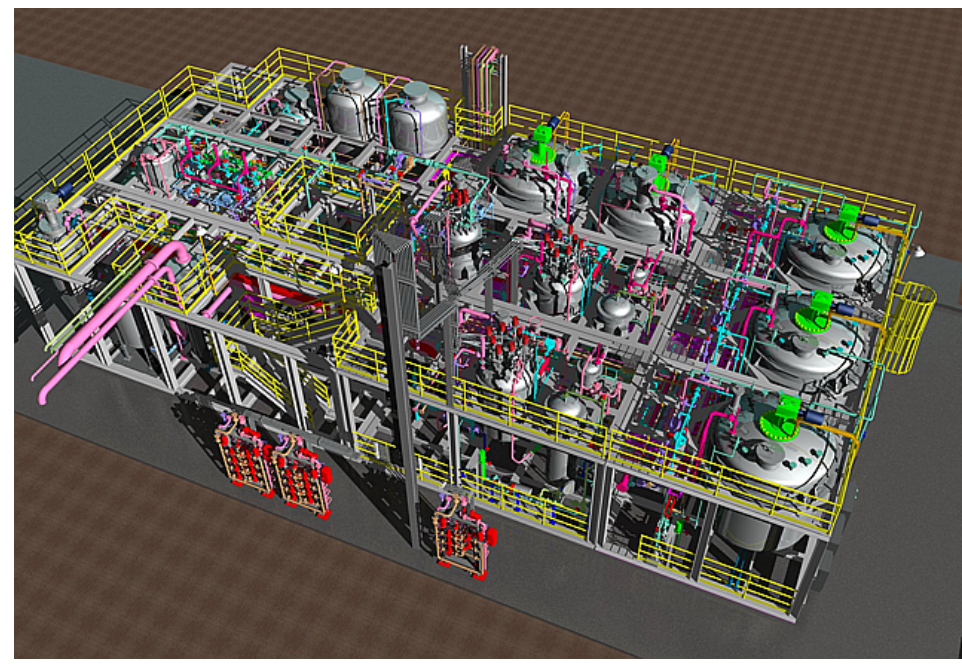

In 2009, Pacific Northwest National Laboratory's Pretreatment Engineering Platform, a one-quarter scale demonstration facility, conducted tests to confirm waste pretreatment processes.

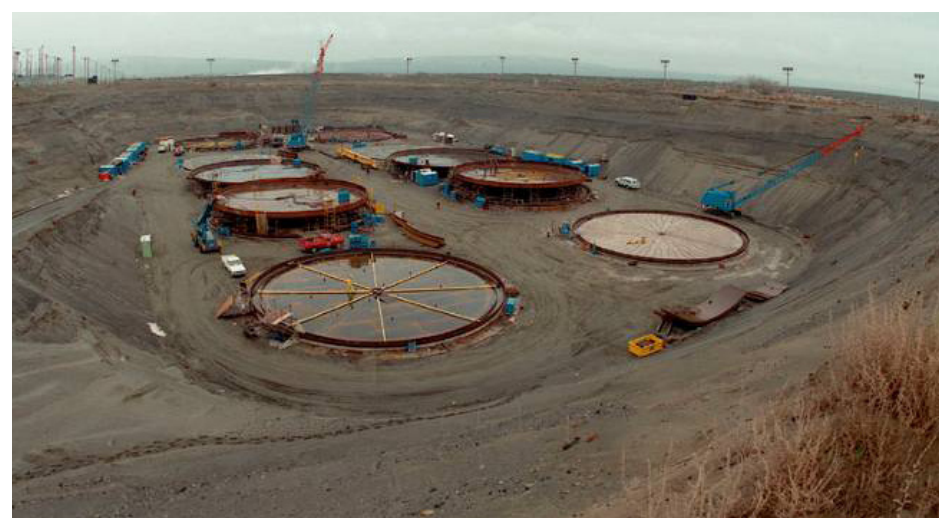

The construction of double-shell tanks between 1968 and 1985 allowed the transfer of wastes from leaking single-shell tanks. The current Hanford Site mission includes managing and treating this waste. Photo courtesy of the U.S. Department of Energy.

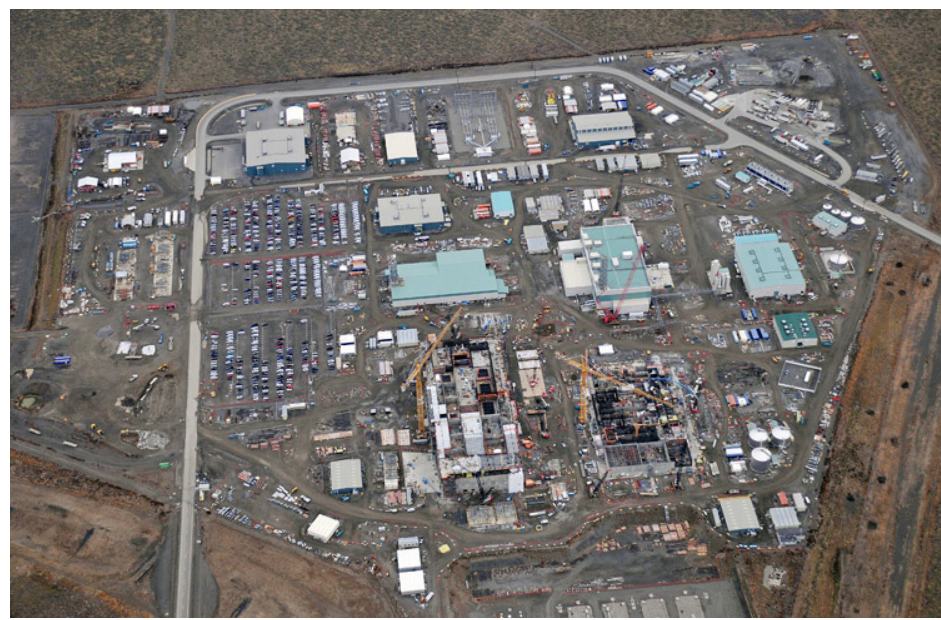

Construction of the Hanford Tank Waste Treatment and Immobilization Plant was approximately 52\% complete at the end of 2009. Photo courtesy of Bechtel National, Inc. 


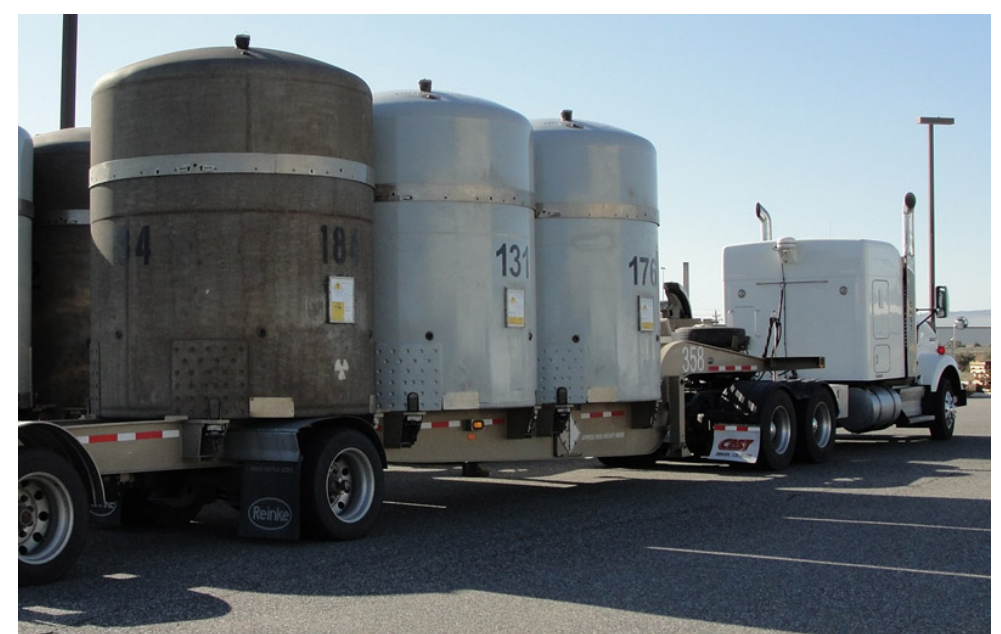

Shipping of transuranic waste to the Waste Isolation Pilot Plant in New Mexico resumed in early 2010 due to American Recovery and Reinvestment Act of 2009 funding. Photo courtesy of CH2M HILL Plateau Remediation Company.
- Accelerate treatment and disposal of mixed low-level waste and the retrieval of transuranic waste and its shipment off the Hanford Site.

- Accelerate cleanup of excess facilities on the Central Plateau (200-East and 200-West Areas).

- Accelerate cleanup and protection of groundwater beneath the Hanford Site.

- Clean up other Hanford Site facilities that are considered urgent risks.
DOE Order 5400.5,

Change 2, establishes

standards and

requirements to

protect members of

the public and the

environment from

undue radiation

exposure.

\section{SITE CLOSURE ACTIVITIES}

DOE Order 5400.5, Change 2, "Radiation Protection of the Public and the Environment," provides the principle requirements for the control and release of Hanford Site property containing residual radioactivity. These requirements ensure that property is evaluated, radiologically characterized, and decontaminated before release; the level of residual radioactivity meets or exceeds DOE authorized limits and is as near background levels as is reasonably practicable; all releases are certified, verified, documented, and reported; public participation needs are addressed; and records are maintained. No property with detectable residual radioactivity was released from the Hanford Site in 2009.

\section{COLUMBIA RIVER CORRIDOR}

Activities continued during 2009 to clean up the Columbia River Corridor. Long-term stewardship focuses on achieving end-state closure and transition of the Columbia River Corridor. Elements include risk assessment activities, orphan site evaluations, remedial action reports, and long-term stewardship plans that will provide a basis for independent closure reviews of the 100 and 300 Areas by independent experts. 


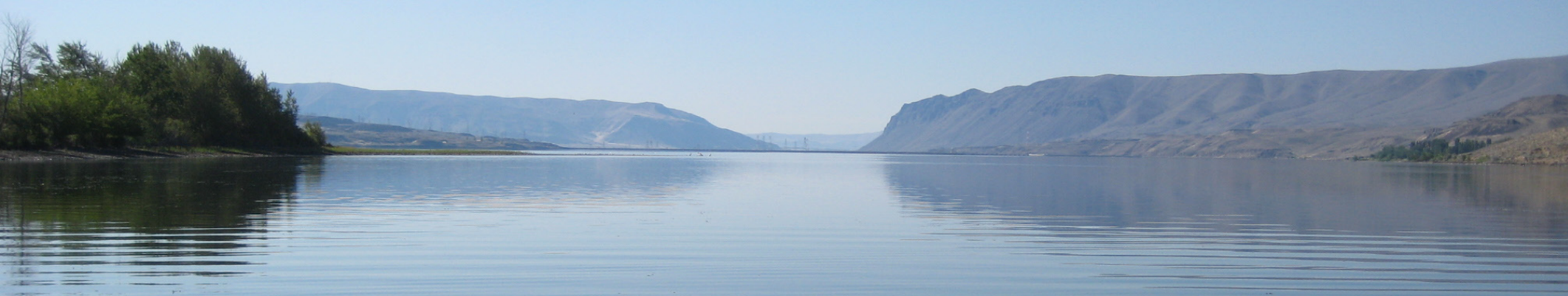

\section{COMPLIANCE WITH ENVIRONMENTAL REGULATIONS}

Federal, state, and local government agencies monitor and enforce compliance with applicable environmental regulations at the Hanford Site. Major agencies include the U.S. Environmental Protection Agency (EPA), Washington State Department of Ecology, Washington State Department of Health, and Benton Clean Air Agency. These agencies issue permits, review compliance reports, participate in joint monitoring programs, inspect facilities and operations, and/or oversee compliance with regulations. A key feature in the Hanford Site compliance program is the Hanford Federal Facility Agreement and Consent Order (also known as the Tri-Party Agreement). The Tri-Party Agreement is an agreement between DOE, EPA, and the Washington State Department of Ecology delineating specific requirements, actions, plans, and schedules required to achieve compliance with the Comprehensive Environmental Resource, Compensation, and Liability Act of 1980 (CERCLA) and Resource Conservation and Recovery Act of 1976 (RCRA) regulations and provisions. The Tri-Party Agreement is continually evolving and is under review to meet changing conditions as cleanup requirements have progressed.
The Clean Water Act of 1977 established goals to control pollutants discharged to surface waters, providing for the restoration and maintenance of water quality. Photo courtesy of Bradley Johns. 
Both the DOE Richland Operations Office and DOE Office of River Protection recognize the importance of maintaining a program of self-assessment and regulatory reporting to assure that environmental compliance is achieved and maintained at the Hanford Site.

Compliance with federal acts in 2009 is summarized in the following table.

\section{COMPLIANCE WITH FEDERAL ACTS ON THE HANFORD SITE IN 2009}

\section{Regulation}

American Indian Religious Freedom Act; Antiquities Act of 1906; Archaeological and Historic Preservation Act of 1974; Archaeological Resources Protection Act of 1979; Historic Sites Act of 1935; National Historic Preservation Act of 1966; and Native American Graves Protection and Repatriation Act of 1990

Atomic Energy Act of 1954

Proper management of radioactive materials.

Clean Air Act

Clean Water Act of 1977 Point-source discharges to U.S. surface waters.

Air quality, including emissions from facilities and from unmonitored sources.

\section{Status}

During 2009, 167 cultural resource reviews were requested on the Hanford Site. DOE determined that 154 activities would not affect cultural resources and were exempt from further review; the remaining 13 requests required full reviews. Fifty-one cultural resources sites were visited in 2009 to assess the effects of erosion, weathering, and unauthorized excavation and collection. Ten new archaeological sites or new isolated finds were recorded on the Hanford Site in 2009.

Two unauthorized excavation incidents were documented as Archaeological Resources Protection Act of 1979 violations.

In 2009, two DOE regulations and directives pertaining to the management and control of radioactive materials on the Hanford Site were issued or underwent significant revision. In addition, five technical standards or handbooks underwent revisions.

In coordination with the Washington State Department of Health and the Benton Clean Air Agency, the Washington State Department of Ecology issued Renewal 1 of the Hanford Site air operating permit for a period of 5 years, effective January 1, 2007. One revision to the air operating permit was approved in 2009. The Washington State Department of Health, the Washington State Department of Ecology, and the Benton Clean Air Agency conducted over 25 inspections in 2009; all were in compliance.

The Hanford Site has one National Pollutant Discharge Elimination System permit, one storm water permit, and several state sanitary wastewater discharge permits. There were no permit violations in 2009.

Sites already contaminated by hazardous materials.
Comprehensive Environmental

Response, Compensation, and Liability
Act of 1980 (CERCLA)

Institutional controls are implemented and maintained in accordance with CERCLA decision documents. During 2009, field inspections of institutional controls at waste sites were performed in the 100-B/C, 100-D, 100-H, 100-N Areas, and the 618-13 waste site in the 300 Area. Warning sign information was updated at the 100-D Area in response to this inspection. No public trespass events occurred in 2009, and approved excavation permits were in use.
Emergency Planning \& Community Right-to-Know Act of 1986
The public's right to information about hazardous materials in the community and the establishment of emergency planning procedures.
In early 2010, Hanford Site officials issued the 2009 Hanford Site Tier Two Emergency and Hazardous Chemical Inventory report to the Washington State Department of Ecology's Community RightTo-Know Unit; local emergency planning committees for Benton, Franklin, and Grant Counties; and both the city of Richland and Hanford Site fire departments. The 2009 Hanford Site Toxic Chemical Release Inventory was released June 24, 2010.

Endangered Species Act of 1973
Rare plant and animal species.
Numerous plants and animals on the Hanford Site are federal- or state-listed as endangered, threatened, sensitive, or candidate species. Ecological compliance reviews are conducted prior to project initiation on the Hanford Site to prevent adverse impacts to biological resources, including listed species. In 2009, 286 reviews were performed, including 164 ecological compliance reviews for general site activities and 122 reviews for environmental restoration activities. 


\section{COMPLIANCE WITH FEDERAL ACTS ON THE HANFORD SITE IN 2009}

\section{Regulation}

Federal Insecticide, Fungicide, and Rodenticide Act

Migratory Bird Treaty Act 1969 (NEPA)

National Environmental Policy Act of

Pollution Prevention Act of 1990

Resource Conservation and Recovery Act of 1976 (RCRA)

Safe Drinking Water Act of 1974

\section{What It Covers}

Storage and use of pesticides.

Migratory birds or their feathers, nests, or eggs.

Environmental impact statements for major federal projects that have the potential to significantly affect the quality of the human environment.

\section{Status}

On the Hanford Site, pesticides are applied by commercial pesticide operators licensed by the state.

All Hanford Site projects with a potential to affect federal- or statelisted species of concern complied with the requirements of this Act by using an ecological compliance review process to minimize adverse impacts to migratory birds.

In October 2009, DOE released the Draft Tank Farm Closure and Waste Management Environmental Impact Statement for the Hanford Site, Richland, Washington for review and comment. Scope includes tank waste treatment, single-shell tank closure, reanalysis and integration of groundwater impacts, reanalysis of onsite disposal alternatives, and decommissioning of the Fast Flux Test Facility.

In 2009, 4,400 tons of sanitary and hazardous wastes were recycled through site-wide programs administered through the Mission Support Contract on the Hanford Site.

wastes by treatment, control, reuse, and/or recycling.

Tracking hazardous waste from generator to treatment, storage, or disposal (referred to as cradle-to-grave management).

DOE is operating under an expired facility RCRA permit at the Hanford Site while the Washington State Department of Ecology drafts a new permit. During 2009, two revisions to the Hanford Facility RCRA Permit Part A Form were submitted to the state for review and approval. Washington State Department of Ecology performed 10 RCRA inspections on the Hanford Site during 2009 to assess compliance with applicable requirements. Three RCRA non-compliance documents were received at the Hanford Site in 2009: 1) Notice of Non-Compliance at the 331-C Facility regarding training and dangerous waste record-keeping; 2) Notice of Non-Compliance for failure to provide secondary containment at the Waste Receiving and Processing Facility; and 3) violations regarding labeling and dating of recyclables at the 616 Waste Handling Facility. All issues were resolved with no impact to the environment.

\section{There were nine public drinking water systems on the Hanford} Site in 2009. The systems were monitored for radiological and chemical contaminants and disinfection residuals and byproducts. There were no microbiological detections during 2009, and all chemical concentrations in Hanford Site drinking water were well below the maximum contaminant levels established by the EPA. Systems demonstrated compliance with the filtration and disinfection treatment technique requirements and limits for disinfectant residuals and disinfection byproducts.

Toxic Substances Control Act
Hazardous chemical regulation and tracking; primarily polychlorinated biphenyls (PCBs).
During 2009, the 2008 PCB annual document log report for the Hanford Site and a 2008 PCB annual report were submitted to the EPA as required. EPA-approved risk-based disposal approvals were used in 2009 for retrieving waste from selected single-shell underground waste storage tanks; for the management of sludge from the K Basins; and continued storage of two water tower tanks containing PCB-contaminated paint. 


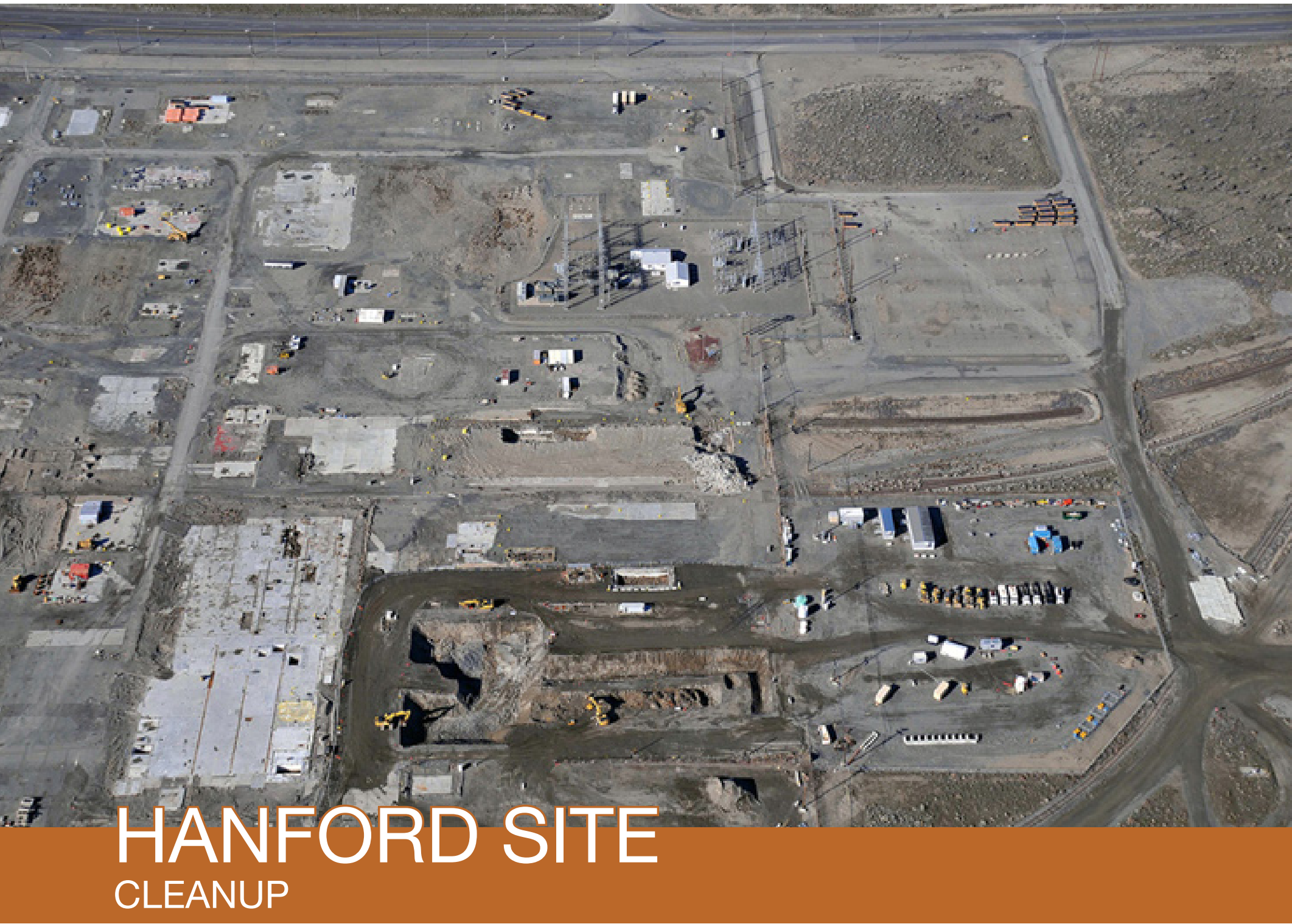

Cleanup of the 300 Area continued during 2009 with the removal of 95,000 tons of contaminated soil. Photo courtesy of the U.S. Department of Energy.

\section{CLEANUP OPERATIONS IN 2009}

Hanford Site cleanup includes remediation of former waste disposal sites and decommissioning of inactive facilities.

Since cleanup activities began at the Hanford Site, the primary focus has been on former liquid effluent waste disposal sites. After over 10 years of progress, the number of liquid effluent waste disposal sites requiring remediation has been reduced, and cleanup activities are now focused on the remediation of waste burial grounds. The volume of contamination in waste burial grounds is less than in liquid effluent waste disposal sites; however, the burial grounds 
may contain unknown materials, which could result in the need for additional time for waste characterization and proper disposal.

Remediation of Waste Sites in the 100 Areas. Full-scale remediation of waste sites began in the 100 Areas in 1996. In 2009, remediation focused on waste burial grounds and miscellaneous waste sites in the 100-B/C, 100-D, and 100-H Areas. A total of 639,900 tons of contaminated soil from 100 Areas remediation activities were disposed of at the Environmental Restoration Disposal Facility (near the 200-West Area) during 2009. The bulk of contaminated soil was from the 100-D and $100-\mathrm{H}$ Areas.

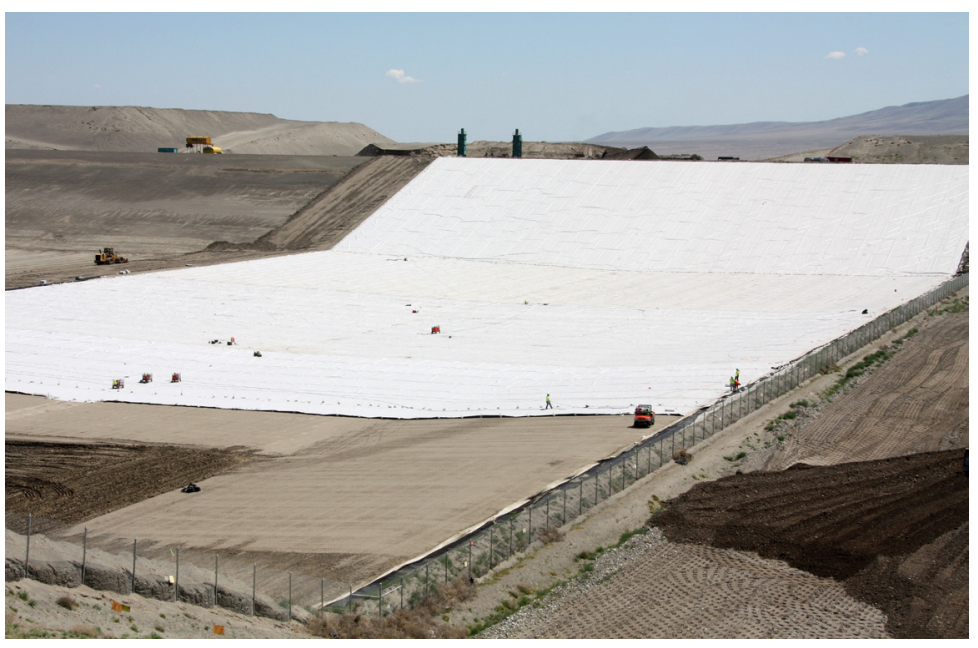

The Environmental Restoration Disposal Facility, located adjacent to the 200-West Area, was constructed to RCRA minimum technology requirements, including a double liner and leachate collection system. Photo courtesy of the U.S. Department of Energy.

\section{SUMMARY OF GROUNDWATER REMEDIATION ACTIVITIES}

\begin{tabular}{|c|c|c|c|c|}
\hline Location & $\begin{array}{l}\text { Startup } \\
\text { Date }\end{array}$ & Contaminant & $\begin{array}{c}\text { Mass Removed } \\
\underline{2009}\end{array}$ & $\begin{array}{l}\text { Mass Removed } \\
\text { Since Startup }\end{array}$ \\
\hline $\begin{array}{l}\text { 100-D Area (100-DR-5 Pump- } \\
\text { and-Treat System) }\end{array}$ & 2004 & Chromium & 97.4 pounds & 554 pounds \\
\hline $\begin{array}{l}\text { 100-D and 100-H Areas } \\
\text { (100-HR-3 Pump-and-Treat } \\
\text { System })^{\text {(a) }}\end{array}$ & 1997 & Chromium & 35.1 pounds & 798 pounds \\
\hline $\begin{array}{l}\text { 100-K Area (100-KR-4 Pump- } \\
\text { and-Treat System) }\end{array}$ & 1997 & Chromium & 17.2 pounds & 766.1 pounds \\
\hline $\begin{array}{l}\text { 100-K Area (KX Pump-and- } \\
\text { Treat System) }\end{array}$ & 2008 & Chromium & 87.5 pounds & 96.1 pounds \\
\hline $\begin{array}{l}\text { 100-K Area (Pump-and-Treat } \\
\text { System near K-West Reactor) }\end{array}$ & 2007 & Chromium & 108.6 pounds & 183.6 pounds \\
\hline $\begin{array}{l}\text { 200-West Area (200-ZP-1 } \\
\text { Pump-and-Treat System) }\end{array}$ & 1994 & Carbon tetrachloride & 825 pounds & 26,400 pounds \\
\hline $\begin{array}{l}\text { 200-West Area (241-T Pump- } \\
\text { and-Treat System) }\end{array}$ & 2007 & Technetium-99 & 0.8 ounce & 1.7 ounces \\
\hline \multirow{4}{*}{$\begin{array}{l}\text { 200-West Area (200-UP-1 } \\
\text { Pump-and-Treat System) }\end{array}$} & 1994 & Carbon tetrachloride & 5.7 pounds & 88.9 pounds \\
\hline & & Nitrate & 13,300 pounds & 104,900 pounds \\
\hline & & Technetium-99 & 0.09 ounce & 0.28 pound \\
\hline & & Uranium & 6.6 pounds & 484 pounds \\
\hline $\begin{array}{l}\text { Waste Management } \\
\text { Area S-SX Extended Purging }\end{array}$ & 2003 & Technetium-99 & 0.004 ounce & 0.02 ounce \\
\hline $\begin{array}{l}\text { 200-West Area (Soil-Vapor } \\
\text { Extraction System) }\end{array}$ & 1991 & Carbon tetrachloride & 390.2 pounds & 175,393 pounds \\
\hline
\end{tabular}




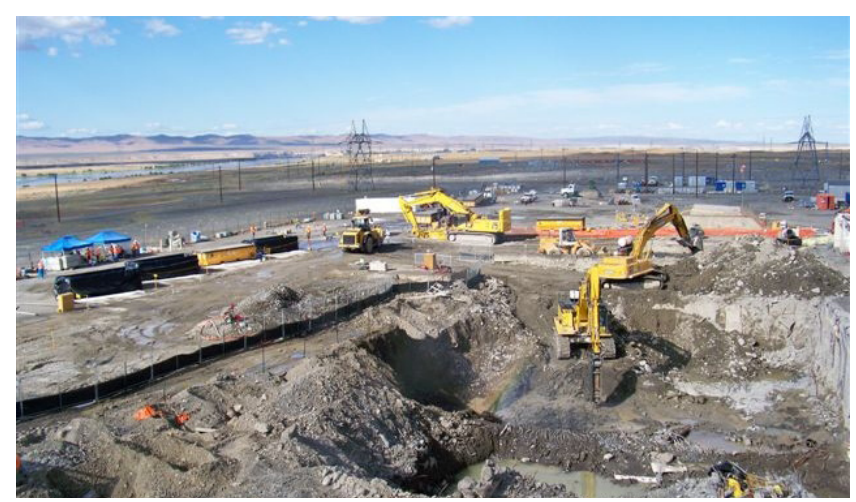

K-East Basin was demolished in 2009 and the structure and basins were removed. Photo courtesy of the U.S. Department of Energy.

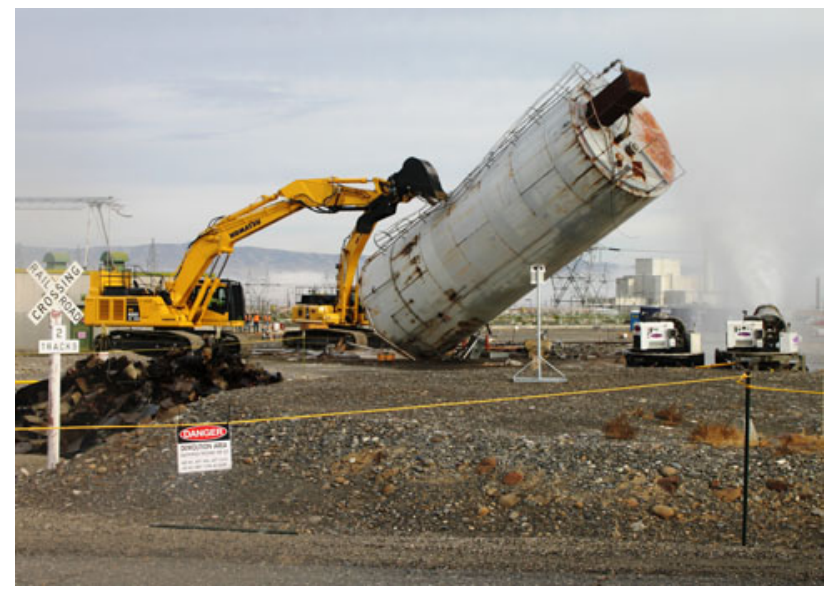

The 183-KW Chemical Storage Silo was demolished in 2009. Photo courtesy of CH2M HILL Plateau Remediation Company.

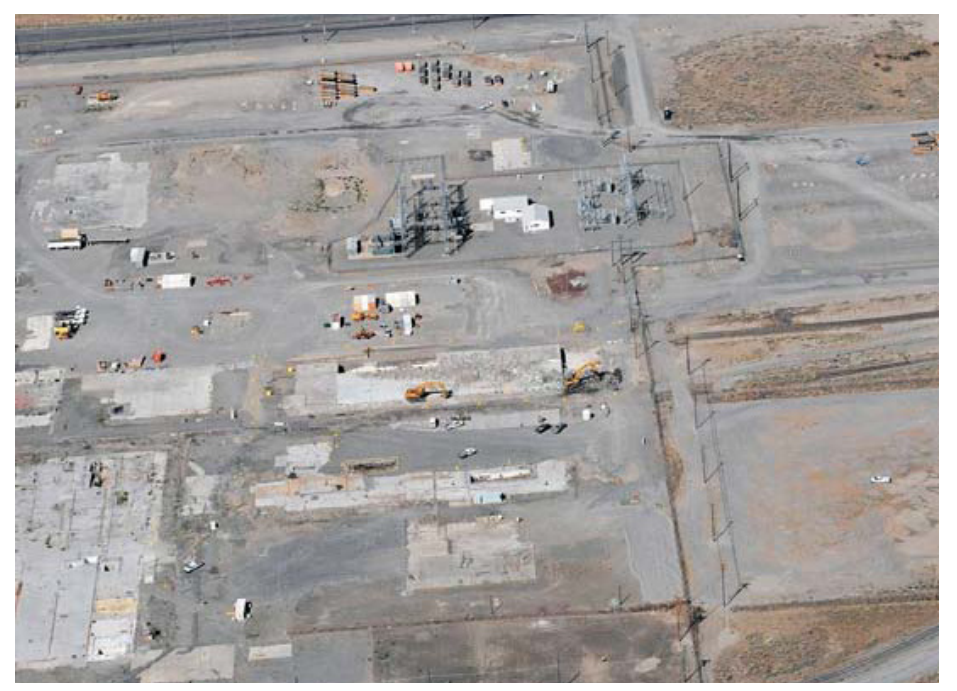

The 618-1 Burial Ground, located at the north end of the 300 Area, was undergoing remediation in 2009. Photo courtesy of Washington Closure Hanford, LLC.
K Basins Closure Activities. The K Basins were two indoor, concrete pools attached to the now-closed K-East and K-West Reactors. For nearly 30 years, these basins contained 2,300 tons of Hanford Site N Reactor spent fuel and a small quantity of irradiated single-pass reactor fuel from older site reactors. This fuel was removed in a major effort that ended in 2004 but fuel corrosion left behind sludge and debris. During 2009, K Basins cleanup continued with the removal of debris from both the K-East and K-West Basins. In September 2009, the $\mathrm{K}$-East Basin was demolished and the structure and basins were removed and disposed of at the Environmental Restoration and Disposal Facility. Radioactive sludge characterization and debris removal continued in the K-West Basin in 2009.

\section{Remediation of Waste Sites on the Central Plateau.} Remedial investigation and feasibility study activities continued during 2009 in the 200-East and 200-West Areas at waste sites that are grouped into a number of CERCLA operable unit groups. Pipeline sampling, geophysical logging, direct-push technology evaluations, and characterization drilling were performed at several operable units, and feasibility studies and proposed plans were issued for several sites.

Remediation of Waste Sites in the 300 Area. In 2009, 95,300 tons of contaminated soil from 300 Area waste sites were removed and disposed of at the Hanford Site Environmental Restoration Disposal Facility. In addition, remediation continued at the 618-1 Burial Ground, located in the northern portion of the 300 Area.

\section{FACILITY DECOMMISSIONING AND DEACTIVATION ACTIVITIES IN 2009}

Decommissioning of Facilities in the 100 Areas.

Decontamination and decommissioning activities 
focused on the 100-N Area in 2009 where several buildings, a lift station, tower, and above and below grade rooms of the 105-N/109-N Reactor Building Complex were demolished. In addition, safe storage enclosure preparations for the 105-N/109-N Reactor Building Complex continued.

Decommissioning of Facilities on the Central Plateau. Surveillance, maintenance, and decontamination or stabilization of over 1,000 waste sites, including former waste disposal cribs, ponds, ditches, trenches, unplanned release sites, and waste burial grounds in the 200-East, 200-West, and 200-North Areas, and a few waste sites on the Fitzner/Eberhardt Arid Lands Ecology Reserve Unit, continued in 2009. Periodic surveillances, radiation surveys, and pesticide and herbicide applications were also conducted. Activities at the Plutonium Finishing Plant included de-inventory of all special nuclear materials; continued cleanout of contaminated equipment; and disposition of excess chemical items and removal of combustibles.

Decommissioning of Facilities in the 300 Area. Deactivation, decontamination, decommissioning, and demolition activities continued in the 300 Area during 2009, focusing on facility and building removal. Eight facilities and buildings were demolished in the 300 Area in 2009.

Deactivation of Facilities in the $\mathbf{4 0 0}$ Area - Fast Flux Test Facility. After multiple studies, a final decision was made by DOE to complete facility deactivation, including removing all nuclear fuel, draining the liquid-sodium systems, and deactivating systems and equipment to place the facility in a low-cost, long-term surveillance and maintenance condition, which was completed in June 2009. Deactivation activities in 2009, included shipment of a polychlorinated biphenylladen transformers for disposal, the shutdown of operating systems (electric, fire suppression, water, ventilation, etc.), and cleanout and closure of the reactor containment building and supporting facilities.

\section{What is decommissioning?}

When DOE declares a facility as surplus (no longer needed), it is shut down and prepared for decontamination and decommissioning (D\&D). The process is the safe decontamination, dismantling, removal of contamination and structures, and/or the release for reuse of facilities that are no longer active. DOE is conducting $D \& D$ activities on reactors, processing plants, storage tanks, laboratory facilities, and other structures. Decontamination and decommissioning presents many challenges. Work continues at the Hanford Site to decommission facilities in the operational areas.

Adapted from

http://www.lanl.gov/environment/cleanup/ dd.shtml

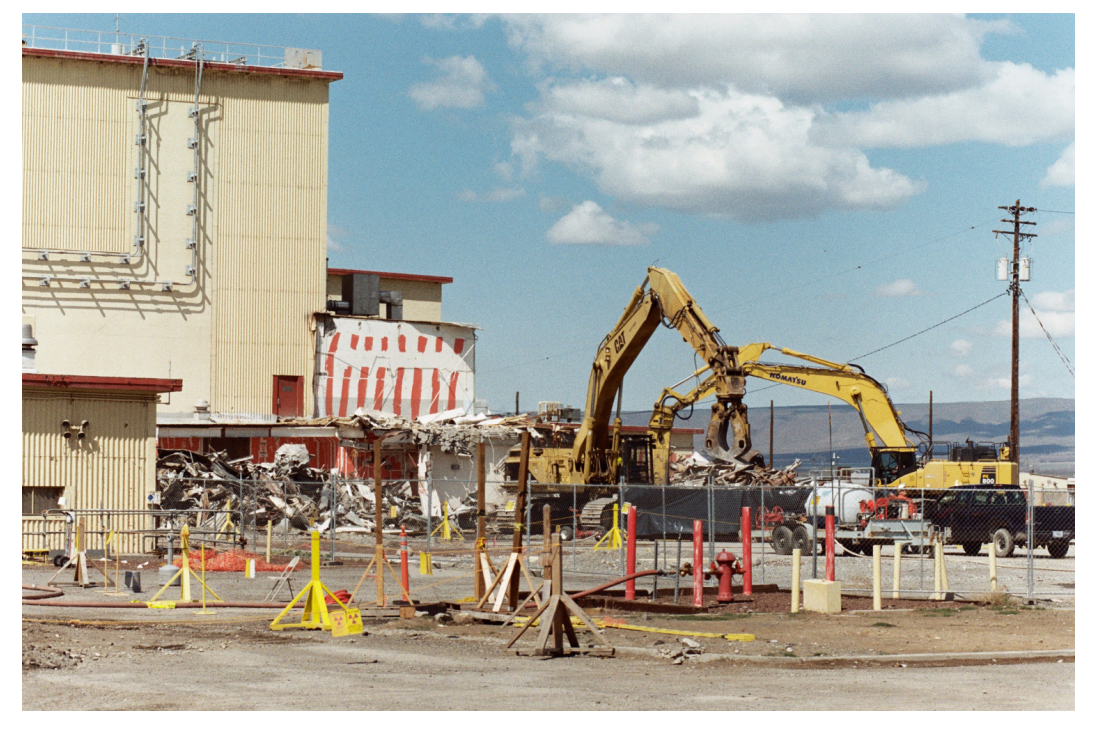

Demolition of 105-N Reactor buildings. Photo courtesy of Washington Closure Hanford, LLC. 


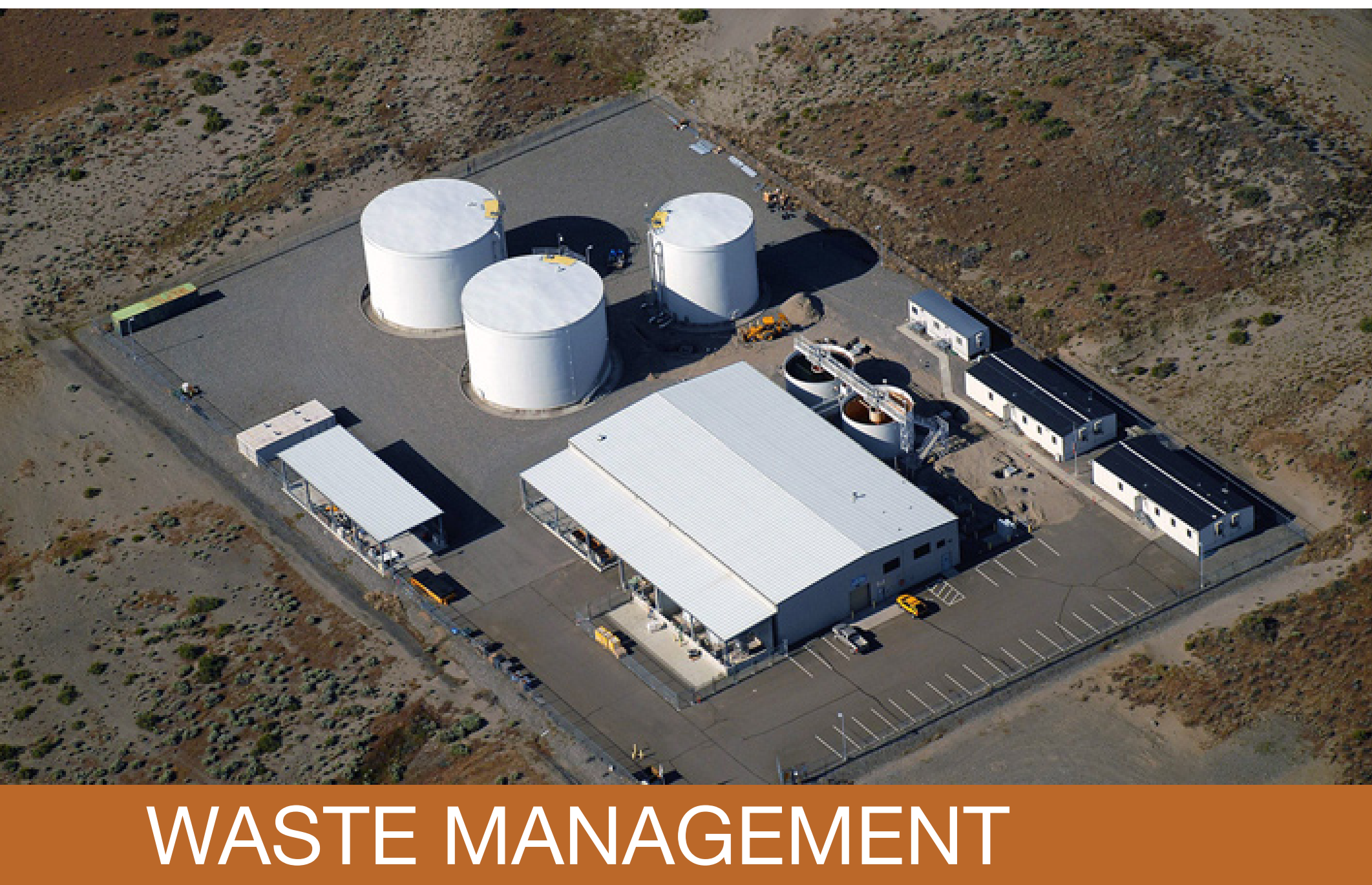

The Effluent Treatment Facility, located in the 200-East Area, treats liquid effluent to remove toxic metals, radionuclides, and ammonia. Photo courtesy of the U.S. Department of Energy.

Hanford Site cleanup activities generate non-regulated, non-radioactive, radioactive, mixed, and hazardous waste. Mixed waste contains both radioactive and hazardous non-radioactive substances. Hazardous waste contains either dangerous waste or extremely hazardous waste, or both. This waste is handled and prepared for safe storage at the site or shipped to offsite facilities for treatment and disposal.

In addition to newly generated waste, significant quantities of waste remain from years of nuclear materials production and waste management activities. Most waste from past operations at the Hanford Site resides in underground storage tanks and in former waste disposal sites, or is temporarily stored until it can be cleaned up, disposed of, or placed in permanent safe storage.

Management of Solid Waste. Waste management at the Hanford Site in 2009 included the treatment, storage, and disposal of solid waste. Onsite 
solid waste facilities include the Central Waste Complex, Waste Receiving and Processing Facility, T Plant Complex, Environmental Restoration Disposal Facility, Waste Encapsulation and Storage Facility, and low-level burial grounds.

The Central Waste Complex can store as much as 27,200 cubic yards of waste. This capacity is adequate to store the projected volumes of low-level, transuranic, and mixed waste, as well as radioactively contaminated polychlorinated biphenyls generated from Hanford Site cleanup activities, assuming on-schedule treatment of the stored waste. Treatment reduces the amount of waste in storage and makes room for newly generated mixed waste. In 2009, the volume of waste stored at this complex totaled approximately 3,800 cubic yards.

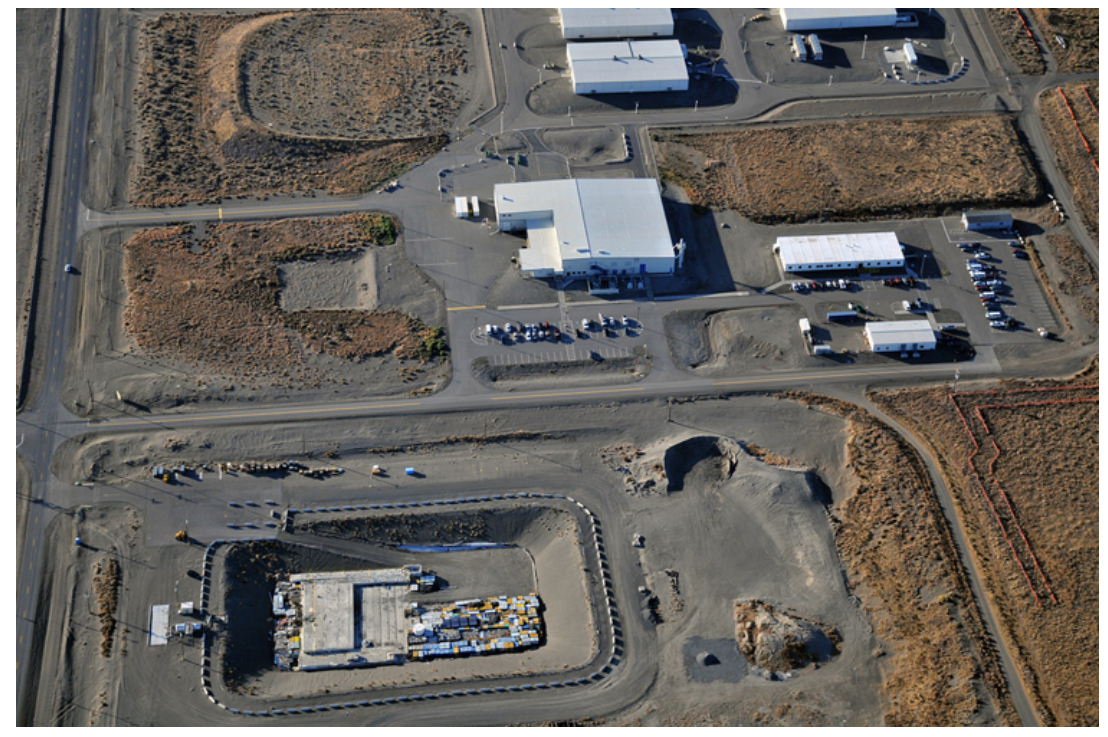

Waste destined for the Waste Receiving and Processing Facility includes stored waste as well as newly generated waste from current Hanford Site cleanup activities. The waste consists primarily of contaminated cloth, paper, rubber, metal, and plastic. This facility treated and shipped 215 cubic yards of waste offsite in 2009.

The T Plant Complex in the 200-West Area provides waste treatment, storage, and decontamination services for the Hanford Site and offsite facilities. In 2009, nine hundred and forty-nine 208-liter (55-gallon) drum equivalents of transuranic waste were repackaged to meet offsite waste acceptance criteria.

Two defueled reactor compartments from the U.S. Navy were shipped to Trench 94 in the 200-East Area in 2009. The total number of Navy reactor compartments received to date is 120 .

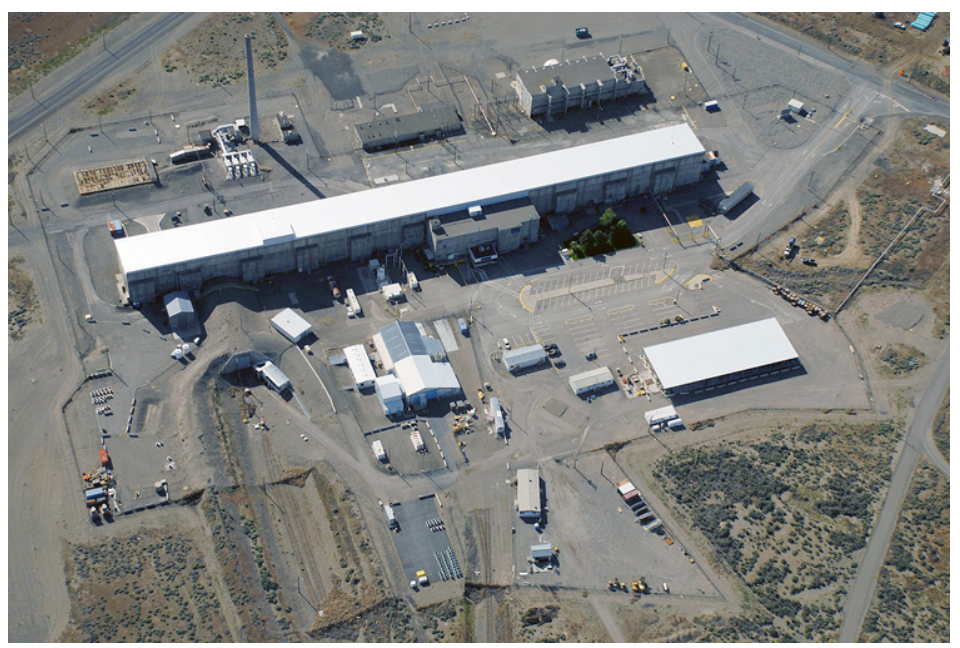

T Plant Complex, located in the 200-West Area provides waste treatment, storage, and decontamination services. Photo courtesy of the U.S. Department of Energy.

During 2009, approximately 930,000 tons of
remediation waste were disposed of at the Environmental Restoration Disposal Facility. Approxi-

The Waste Receiving and Processing facility, located in the 200-West Area, treats low-level and transuranic wastes for permanent disposal. Photo courtesy of the U.S. Department of Energy. mately 9 million tons of remediation waste have been disposed of at the Environmental Restoration Disposal Facility from initial operations startup through 2009. 


\section{HANFORD SITE WASTE SUMMARY FOR 2009}

\begin{tabular}{|c|c|c|}
\hline Activity & Waste Type & Amount \\
\hline \multirow[t]{2}{*}{ Solid waste generated during onsite cleanup activities } & Solid mixed waste & 281 tons \\
\hline & Radioactive waste & 696 tons \\
\hline \multirow{2}{*}{$\begin{array}{l}\text { Solid waste received at the Hanford Site from offsite (includes Hanford Site } \\
\text { generated waste treated by an offsite contractor and returned to the Hanford Site } \\
\text { as newly generated waste) }\end{array}$} & Solid mixed waste & 257 tons \\
\hline & Radioactive waste & 196 tons \\
\hline \multirow[t]{3}{*}{ Dangerous waste shipped off the Hanford Site } & $\begin{array}{l}\text { Containerized waste } \\
\text { (dangerous waste only) }\end{array}$ & 47 tons \\
\hline & Bulk solids & 83 tons \\
\hline & Bulk liquids & 2 tons \\
\hline $\begin{array}{l}\text { Waste dispositioned and shipped offsite from the Waste Receiving and Processing } \\
\text { Facility }\end{array}$ & Solid waste & 5,800 cubic feet \\
\hline Waste disposed of at the Environmental Restoration Disposal Facility & Solid waste & 930,000 tons \\
\hline Waste treated or directly disposed of at Trenches 31 and 34 & Mixed low-level solid waste & 35,500 cubic feet \\
\hline Volume of liquid effluent treated at the Effluent Treatment Facility & $\begin{array}{l}\text { Wastewater containing toxic metals, } \\
\text { radionuclides, ammonia, and } \\
\text { organic compounds }\end{array}$ & 22 million gallons \\
\hline Volume of aqueous waste received at the Liquid Effluent Retention Facility & $\begin{array}{l}\text { Wastewater containing low levels of } \\
\text { organic compounds and tritium }\end{array}$ & 25.4 million gallons \\
\hline Volume of effluent disposed of at the 200 Area Treated Effluent Disposal Facility & $\begin{array}{l}\text { Uncontaminated, treated liquid } \\
\text { waste }\end{array}$ & 340 million gallons \\
\hline $\begin{array}{l}\text { Volume of wastewater treated and disposed of at the } 300 \text { Area Treated Effluent } \\
\text { Disposal Facility }\end{array}$ & Industrial wastewater & 426 million gallons \\
\hline Volume of wastewater treated (evaporated) at the 242-A Evaporator & Liquid waste from single-shell tanks & 960 thousand gallons \\
\hline $\begin{array}{l}\text { Waste volume pumped from underground single-shell waste storage tanks to double- } \\
\text { shell waste storage tanks (includes flush/dilution water) }\end{array}$ & Liquid waste & 102 thousand gallons \\
\hline Waste volume in underground single-shell waste storage tanks at the end of 2009 & Liquid waste & 29.7 million gallons \\
\hline Waste added to underground double-shell waste storage tanks & Liquid waste & 325 thousand gallons \\
\hline Waste volume in underground double-shell waste storage tanks at the end of 2009 & Liquid waste & 26.0 million gallons \\
\hline
\end{tabular}

Nearly 30 million

gallons of waste

remained in single-shell

underground waste

storage tanks at the

end of 2009.
The low-level burial grounds consist of eight burial grounds located in the 200-East and 200-West Areas that are used for disposal of low-level waste and mixed waste (i.e., low-level radioactive waste with a dangerous waste component). On June 23, 2004, DOE issued a record of decision for the Solid Waste Program at the Hanford Site. Part of the record of decision stated that DOE will dispose of low-level waste in lined disposal facilities. Only two of the low-level burial ground trenches are lined (Trenches 31 and 34); therefore, since that date (June 23, 2004), all low-level waste-as well as mixed low-level waste- has been disposed in these two trenches. In 2009, a total of 35,500 cubic feet of waste was disposed in Trenches 31 and 34, and 23,000 cubic feet of retrievably stored waste was retrieved from low-level burial grounds.

The Waste Encapsulation and Storage Facility stores strontium and cesium encapsulated salts in double containment stainless-steel capsules in underwater 
pool cells, providing safe storage. The water provides cooling and shielding for the capsules that are considered sealed sources.

The Integrated Disposal Facility, completed in 2006 and currently not operational, is an expandable RCRA-compliant landfill located in the southcentral part of the 200-East Area with a waste disposal capacity of approximately 5.8 million cubic feet. The facility will receive immobilized lowactivity tank waste and other low-level radioactive waste from the Hanford Tank Waste Treatment and Immobilization Plant.

Management of Liquid Waste. Liquid effluent is stored, treated, or disposed in facilities that comply with federal and state regulations and facility permits.

The Effluent Treatment Facility, located in the 200-East Area, treats liquid effluent to remove toxic metals, radionuclides, and ammonia, and destroy organic compounds. The treated effluent is stored in tanks, sampled and analyzed, and discharged onsite to the State-Approved Land Disposal Site. Approximately 22 million gallons of wastewater was treated and disposed of in 2009.

Approximately 25 million gallons of wastewater was received at the Liquid Effluent Retention Facility for interim storage in 2009. Approximately 17 million gallons of liquid waste were stored at this facility at the end of 2009 .

In 2009, 340 million gallons of uncontaminated effluent were disposed of at the 200 Area Treated Effluent Disposal Facility. This facility consists of buried pipelines, three pumping stations, and two 5-acre ponds located east of the 200-East Area. The major source of this effluent was uncontaminated cooling water and steam condensate from various Hanford Site facilities.

Industrial wastewater generated primarily from laboratories, research facilities, and office buildings

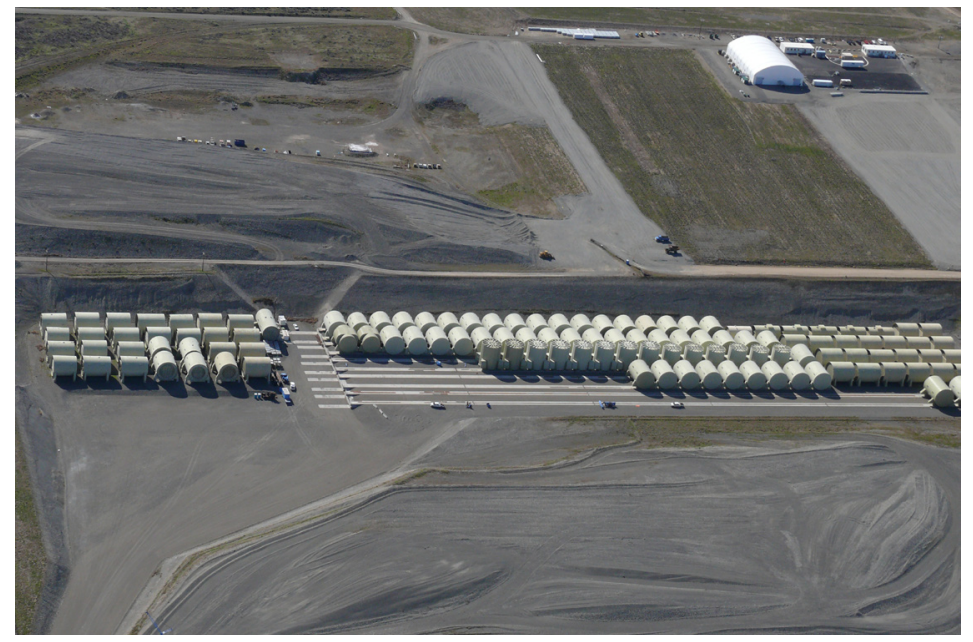

Two defueled submarine reactor compartments were placed in Trench 94 in the 200-East Area in 2009. Photo courtesy of Robert Mueller.

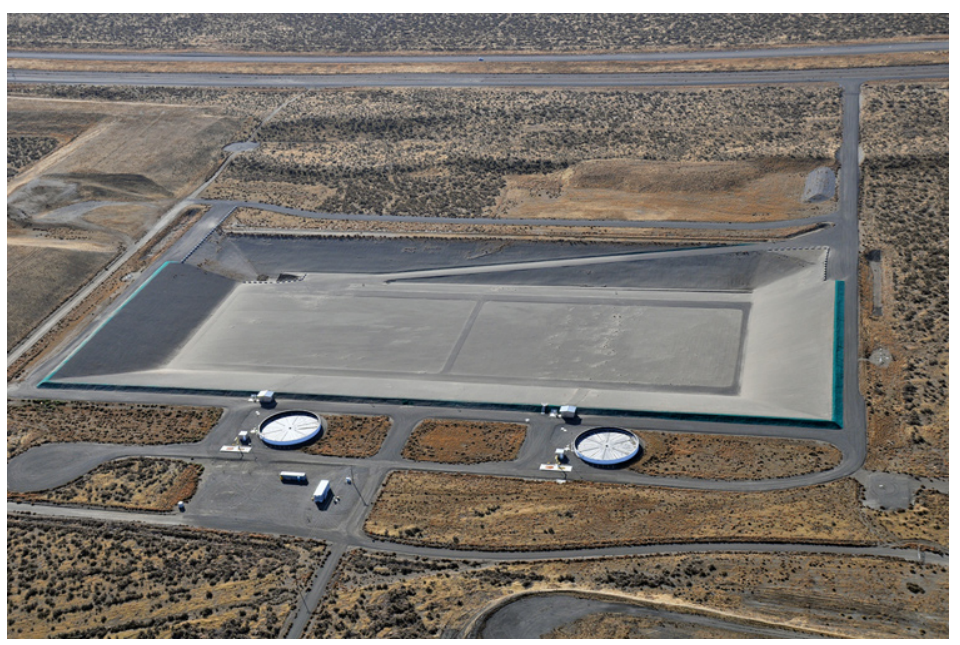

The Integrated Disposal Facility, located in the 200-East Area, is a newly constructed, unused landfill available for future waste disposal. Photo courtesy of the U.S. Department of Energy.

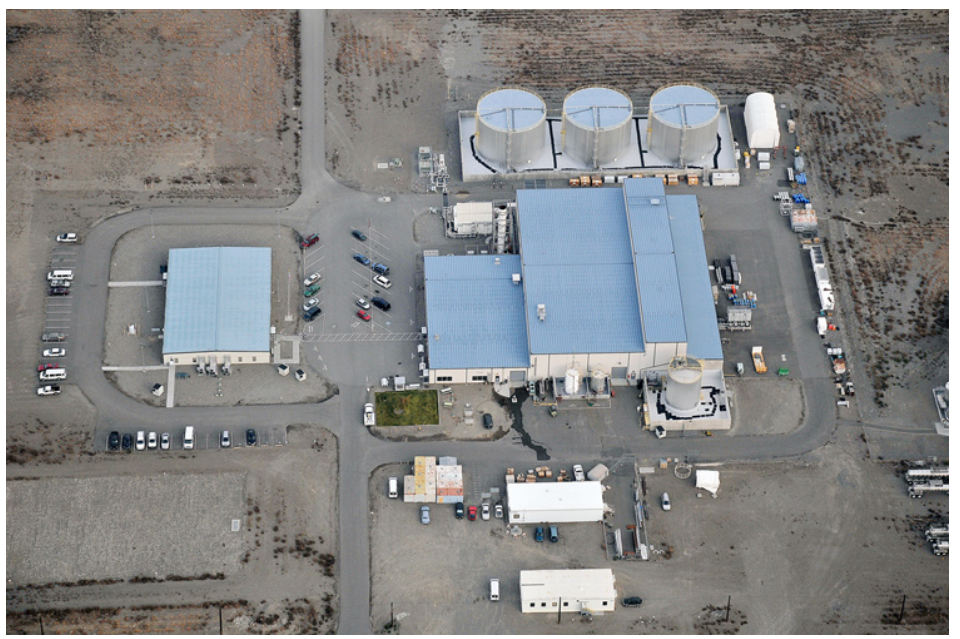

The Liquid Effluent Retention Facility, located in the 200-East Area, temporarily stores liquid process condensate. Photo courtesy of the U.S. Department of Energy. 


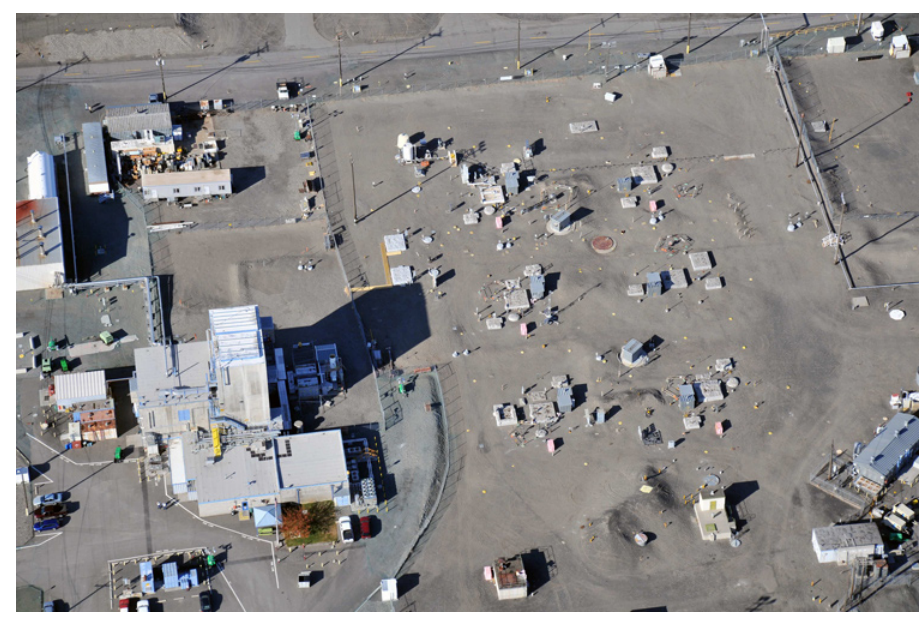

The 242-A Evaporator concentrates liquid waste from the single-shell tanks, reducing the volume transferred to the double-shell tanks. Photo courtesy of the U.S. Department of Energy.

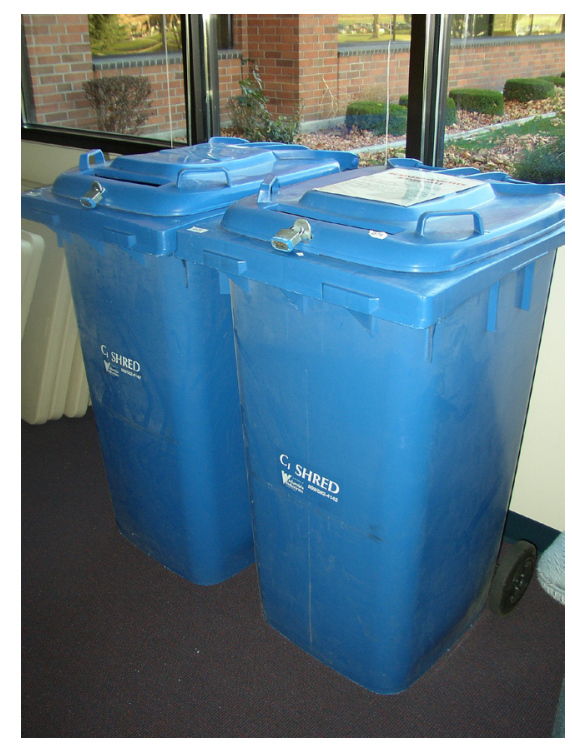

Mixed office paper and cardboard were recycled as part of the Pollution Prevention and Waste Minimization Program. in the 300 Area is collected and treated in the 300 Area Treated Effluent Disposal Facility. The wastewater consists of cooling water, steam condensate, and other industrial wastewater. A total of 26 million gallons of industrial wastewater was treated and disposed of during 2009. The 300 Area Treated Effluent Disposal Facility was permanently shut down in September 2009.

The 242-A Evaporator in the 200-East Area concentrates diluted liquid waste from single-shell underground waste storage tanks by evaporation. This reduces the volume of liquid waste sent to the double-shell tanks for storage and reduces the potential need for more doubleshell tanks. In 2009, the 242-A Evaporator completed a successful operating campaign that reduced the volume of waste in two double-shell storage tanks by more than 960,000 gallons.

Underground Waste Storage Tanks. In 2009, 102,000 gallons of waste (including dilution or flush water used in waste retrieval activities) were pumped from single-shell tanks to the double-shell tanks, leaving 30 million gallons of waste remaining in the single-shell tanks. At the end of 2009, there were 26 million gallons of waste in the double-shell tanks.

Hanford Tank Waste Treatment and Immobilization Plant. The Hanford Tank Waste Treatment and Immobilization Plant is being built on 65 acres adjacent to the 200-East Area. This plant will treat radioactive and hazardous waste presently stored in 177 underground tanks. Construction of the four major facilities continued in 2009: a pretreatment facility, a high-level waste vitrification facility, a low-activity waste vitrification facility, and an analytical laboratory, as well as supporting facilities. Overall, the project was approximately $52 \%$ complete at the end of 2009 .

\section{POLLUTION PREVENTION AND WASTE MINIMIZATION}

The Pollution Prevention and Waste Minimization Program is an organized and continuing effort to reduce the quantity and toxicity of hazardous, radioactive, mixed, and sanitary waste generated at the Hanford Site.

In fiscal year 2009 (October 2008 through September 2009), approximately 4,400 tons of sanitary and hazardous wastes were recycled through site-wide programs administered through the Mission Support Contract. 
Concentrations of

radioactive materials

in air are monitored

continuously on and off

the Hanford Site.

americium-241, and a few other isotopes are released in the 100, 200, 300, 400, and 600 Areas of the Hanford Site.

Non-radioactive air pollutants are emitted from power-generating and chemical-processing facilities. These facilities are monitored when activities are known to generate potential pollutants of concern, which include carbon monoxide, gaseous ammonia, lead, nitrogen oxides, particulate matter, sulfur oxides, and volatile organic compounds.

Air emissions data collected in 2009 were comparable to those collected in 2008.

\section{AMBIENT-AIR MONITORING}

Radioactive constituents in air are monitored on the Hanford Site near facilities and operations, at site-wide locations away from facilities, offsite around the perimeter of the site, and in nearby and distant communities.

Ambient-Air Monitoring Near Facilities and Operations. In 2009, ambient air was monitored at 84 locations on the Hanford Site near facilities and operations. Samplers were located primarily at or within approximately 1,640 feet of sites or facilities having the potential for, or a history of, environmental releases. Samples collected from locations at or directly adjacent to Hanford Site facilities had higher radionuclide concentrations than samples collected farther away. In general, radionuclide concentrations in most Hanford Site near-facility samples were greater than levels measured in samples collected offsite. The data also show that concentrations of certain radionuclides were higher and widely variable within different onsite operational areas. Naturally occurring beryllium-7 and potassium-40 were routinely identified.

Several samples from the $100-\mathrm{K}$ and 200 Areas had results greater than $10 \%$ of EPA's concentration values. Elevated results at 100-K East included strontium-90, cesium-137, plutonium-239/240, and americium-241. At 100-K West,

Air samplers on the Hanford Site were located primarily around major operational areas to maximize the ability to detect radiological contaminants resulting from site operations. Photo courtesy of Bradley Johns. cesium-137 was elevated. Results for cesium-137 and plutonium-239/240 were elevated from the 200-East and 200-West Areas, respectively.

Hanford Site-Wide and Offsite Ambient-Air Monitoring. During 2009, samples were collected at 42 continuously operating locations: 23 onsite (sitewide), 11 at site perimeter locations, 7 in nearby communities, and 1 in a distant community. Airborne particle samples were collected at each station biweekly and monitored for gross alpha and gross beta concentrations. 
Biweekly samples were combined into quarterly composite samples and analyzed for gamma-emitting radionuclides. Samples of atmospheric water vapor were collected every 4 weeks and analyzed for tritium at 20 locations. All air sample results showed very low radiological concentrations in 2009 and were below the EPA Clean Air Act dose standard of 10 millirem per year.

\section{LIQUID EFFLUENT MONITORING}

Effluent entering the environment at designated discharge points is sampled and analyzed to determine compliance with applicable Hanford Site discharge permits. Liquid effluent streams from Hanford Site facilities are sampled for gross alpha and gross beta concentrations, as well as for concentrations of selected radionuclides. In 2009, facilities in the 200 Areas discharged radioactive liquid effluent to the ground at a single location, the State-Approved Land Disposal Site. Non-radioactive hazardous materials in liquid effluent are monitored in the 100, 200, 300, and 400 Areas. The non-radioactive effluent is discharged to the State-Approved Land Disposal Site and to the Columbia River. Discharges were in compliance with National Pollutant Discharge Elimination System and state waste discharge permit limitations.
Effluent discharges

are in compliance

with federal and state

discharge permits.

\section{SURFACE-WATER AND SEDIMENT MONITORING}

Samples of surface water and sediment on and near the Hanford Site were collected and analyzed to determine the concentrations of radiological and chemical contaminants attributable to the site. Surface water bodies included the Columbia River, onsite ponds, and offsite irrigation sources. Aquatic sediment was collected from the Columbia River and one onsite pond.

Columbia River Water. During 2009, Columbia River water samples were collected with automated samplers at fixed-location monitoring stations at Priest Rapids Dam and at the city of Richland, Washington, and analyzed for radionuclides. Samples

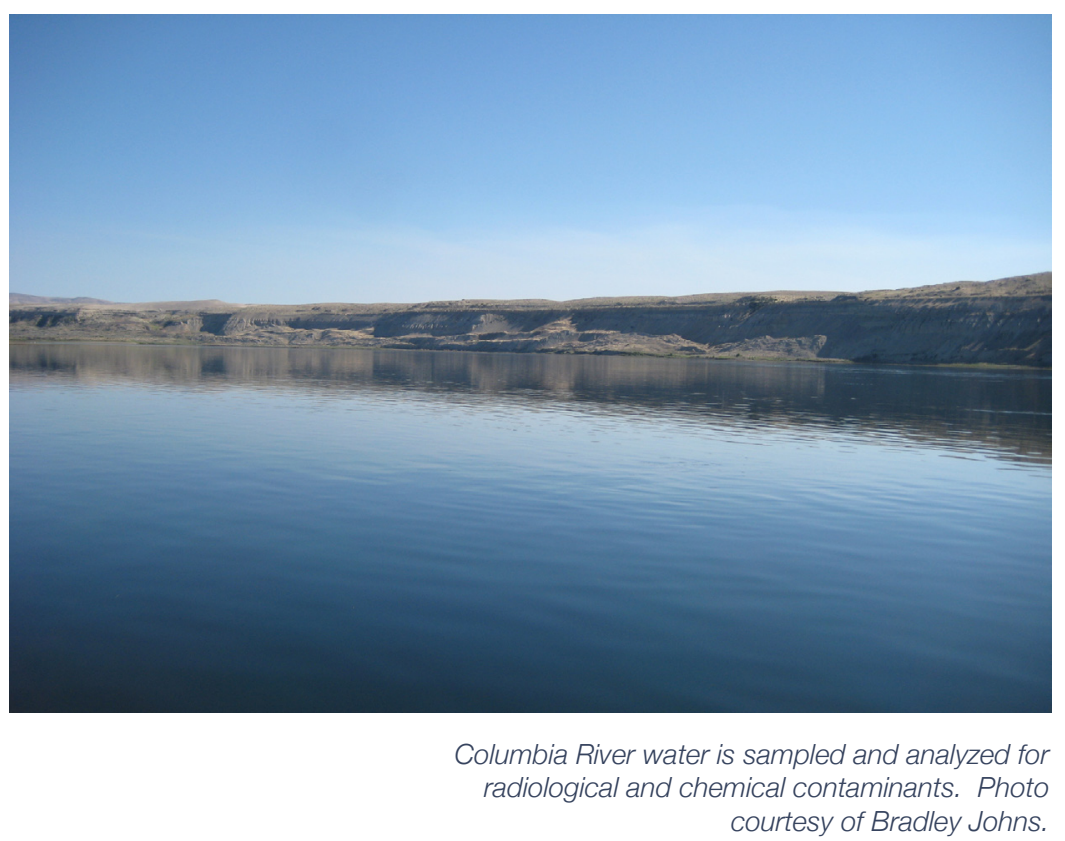




\section{HANFORD SITE MONITORING RESULTS FOR 2009}

\section{What Was Monitored?}

Air

Columbia River Water and Sediment

Columbia River Shoreline Spring Water and Sediment
Radioactive and non-radioactive emissions were monitored at Hanford Site facilities. Air particles and gases were monitored for radioactivity onsite near facilities and offsite. Ambient-air samples were collected at 84 locations near Hanford Site facilities, at 23 locations around the site away from facilities, at 11 site perimeter locations, at 7 nearby community locations, and at 1 distant community location.

Columbia River water and sediment samples were collected from multiple Hanford Reach sampling points and from locations upstream and downstream of the Hanford Site. The samples were analyzed for radioactive and chemical contaminants.

Groundwater beneath the Hanford Site discharges to the Columbia River along the Hanford Site shoreline. Discharges above the water level of the river are identified as shoreline springs. Samples of spring water and sediment were collected at locations along the Hanford Reach.

\section{The Bottom Line}

Radionuclide levels near facilities in 2009 were generally similar to measurements from previous years. One cesium-137 result from the 200-East Area, two plutonium-239/240 results from the 200-West Area, as well as strontium-90, cesium- 137 plutonium-239/240, and americium-241 results from the $100-\mathrm{K}$ Area were greater than $10 \%$ of EPA's concentration values, requiring notifications to the Washington State Department of Health. All measurements of radioactive materials in air around the Hanford Site away from facilities were below DOE-derived concentration guides.

As in past years, small amounts of radioactive materials were detected downriver from the Hanford Site. However, the amounts were far below federal and state limits. During 2009, there was no indication of any deterioration of Columbia River water or sediment quality resulting from operations at the Hanford Site.

Measurements of radiological contaminants in samples collected at the shoreline springs were less than applicable DOE-derived concentration guides. Most of the 2009 chemical sample results were similar to those previously reported. Concentrations of volatile organic compounds were near or below their detection limits in all samples. Trace amounts of chlorinated organic compounds were observed at some locations. Concentrations of most metals were below Washington State ambient surface-water chronic toxicity levels.

Radionuclide concentrations measured in shoreline sediment samples were similar to concentrations measured in Columbia River sediment, with the exception of the 300 Area where uranium concentrations were above the background concentration measured in the sediments from the reservoir behind Priest Rapids Dam. Metals concentrations in all samples were also similar to concentrations measured in Hanford Reach Columbia River sediment samples.

Food and Farm Products Samples of alfalfa, applies, leafy vegetables, milk, potatoes, tomatoes, and wine were collected from locations upwind and downwind of the Hanford Site.

Fish and Wildlife

Game animals and other animals of interest on the Hanford Site and fish from the Hanford Reach of the Columbia River were monitored. Carcass, liver, and muscle samples were analyzed to evaluate radionuclide and metals concentrations.

Radionuclide concentrations in samples of food and farm products were at normal environmental levels.

Samples of whitefish and Canada geese were collected and analyzed. Radionuclide levels in wildlife samples were well below levels that are estimated to cause adverse health effects to animals or to the people who may consume them. Most trace metal concentrations in liver samples were similar to or less than concentrations measured in background samples. Onsite wildlife samples had elevated maximum values for some trace metals.

Soil Eighty-one routine soil samples were collected onsite near facilities and operations in 2009 to verify known radiological conditions.

In general, radionuclide concentrations in routine samples collected from or adjacent to waste disposal facilities in 2009 were higher than concentrations measured in distant communities in previous years. There were 28 instances of radiological contamination in soil samples investigated in 2009 . Of the 28 , 26 were cleaned up and 2 were controlled in a posted area.

Vegetation

Samples of perennial vegetation were collected near Hanford Site facilities and operations in 2009 and analyzed for radiological contaminants. Samples of wild chives were collected from the Hanford Reach and analyzed for radiological and metal concentrations.
Concentrations of radionuclides were comparable to those from previous years and elevated in vegetation samples collected near facilities and operations when compared to concentrations in samples from distant communities collected in previous years. Wild chives had no detectable radionuclides except for naturally occurring potassium-40. Metals concentrations were highest in chive root subsamples. 
were also taken from cross-river transects and near-shore locations near Vernita Bridge, the 100-N Area, Hanford town site, 300 Area, and the city of Richland and analyzed for both radionuclides and chemicals. Radiological constituents of interest included gamma-emitting radionuclides, tritium, strontium-90, technetium-99, uranium-234, uranium-235, uranium-238, plutonium-238, and plutonium-239/240. Gross beta and gross alpha concentrations were also monitored. Chemicals of interest included metals and anions. All radiological contaminant concentrations measured in Columbia River water at the fixed sampling locations during 2009 were less than $1 / 25$ th of the DOE effective dose equivalent standard of 100 millirem per year. Tritium, uranium-234, uranium-238, and naturally occurring potassium- 40 were consistently measured in transect and near-shore samples but all measured concentrations were less than applicable Washington State ambient surface-water quality criteria. Metals and anions were detected in Columbia River transect water samples both upstream and downstream of the Hanford Site. All concentrations measured in 2009 were below regulatory limits.

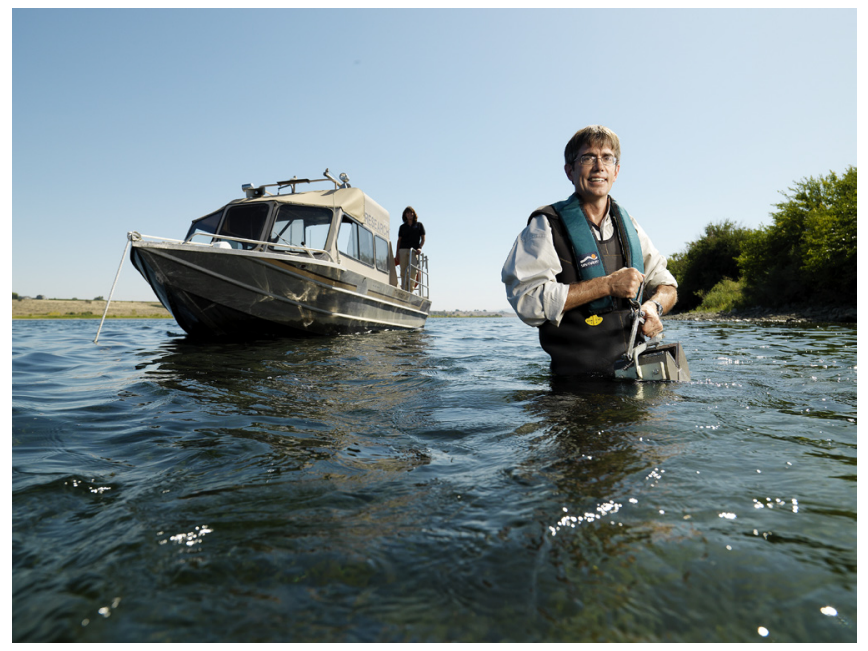

Sediment samples are routinely collected from the Columbia River and analyzed for radionuclides and chemicals.

Sediment from the Columbia River. During 2009, samples of the surface layer of Columbia River sediment were collected from the reservoirs behind Priest Rapids Dam, McNary Dam, and Ice Harbor Dam; slack-water areas along the Hanford Reach; and at the city of Richland shoreline. Radionuclides consistently detected at low levels in Columbia River sediment in 2009 included naturally occurring potassium-40, cesium-137, uranium-234, uranium-235, uranium-238, plutonium-238, plutonium-239/240, and daughter products from naturally occurring radionuclides. Radionuclide concentrations observed during 2009 were similar to those reported for previous years. Detectable amounts of most metals were found in all river sediment samples; however, there are no Washington State freshwater sediment quality criteria for comparison to the measured metals values.

Water and Sediment from Ponds. Two onsite ponds, West Lake and the Fast Flux Test Facility Pond, were sampled in 2009. Water samples were obtained quarterly from both ponds and sediment samples were obtained semiannually from West Lake. All

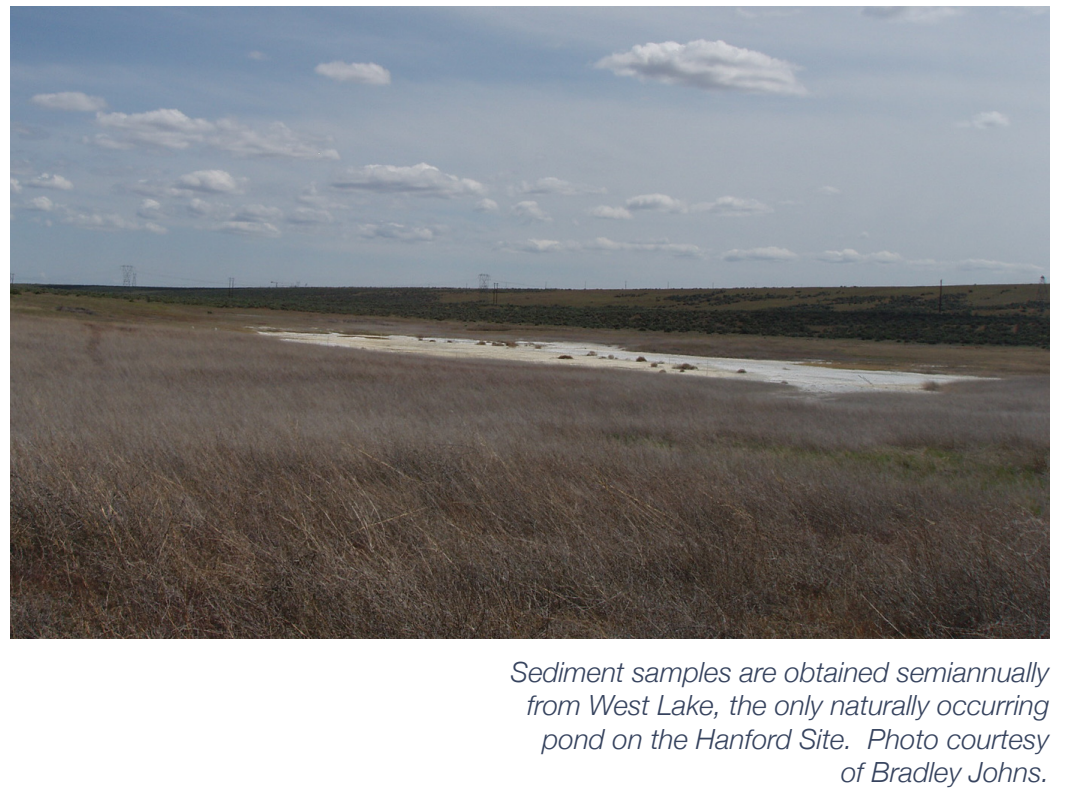


samples were analyzed for tritium, and samples from the Fast Flux Test Facility Pond, were also analyzed for gross alpha, gross beta, and gamma-emitting radionuclides. All radionuclide concentrations in onsite pond water samples

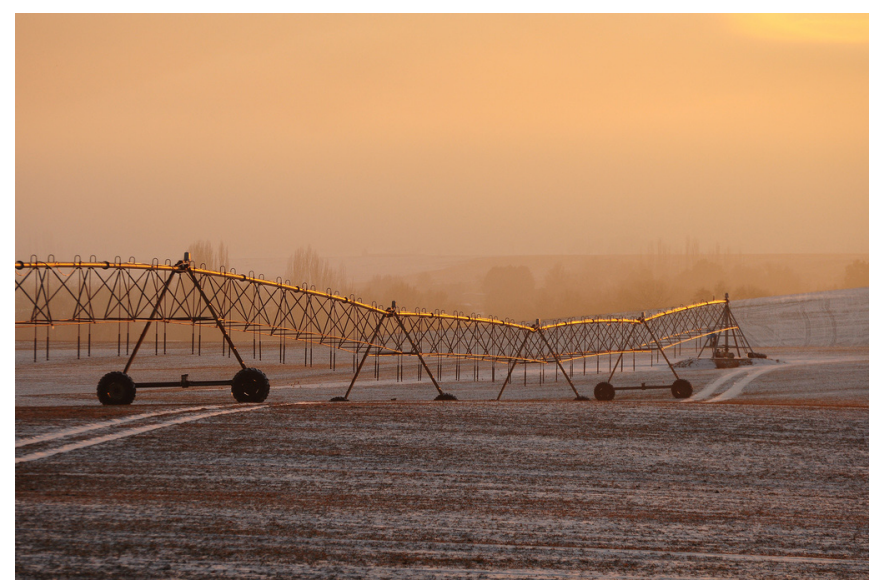

Irrigation water samples are collected from offsite locations. Photo courtesy of Scott Butner. were less than applicable DOE-derived concentration guides and Washington State ambient surface-water quality criteria. Concentrations in sediment samples were similar to concentrations measured in prior years.

Offsite Irrigation Water. In 2009, water samples were collected from an irrigation canal in the Riverview area of Pasco (located east of the Columbia River downstream from the Hanford Site), and from an irrigation water supply in Benton County near the southern boundary of the Hanford Site. All radionuclide concentrations were below applicable DOE-derived concentration guides and Washington State ambient surface water quality criteria. With the exception of tritium and uranium results obtained from the Horn Rapids irrigation pumping station, all radionuclide concentrations were detected at the same levels detected in Columbia River water obtained upstream of the Hanford Site.

\section{COLUMBIA RIVER SHORELINE SPRINGS MONITORING}

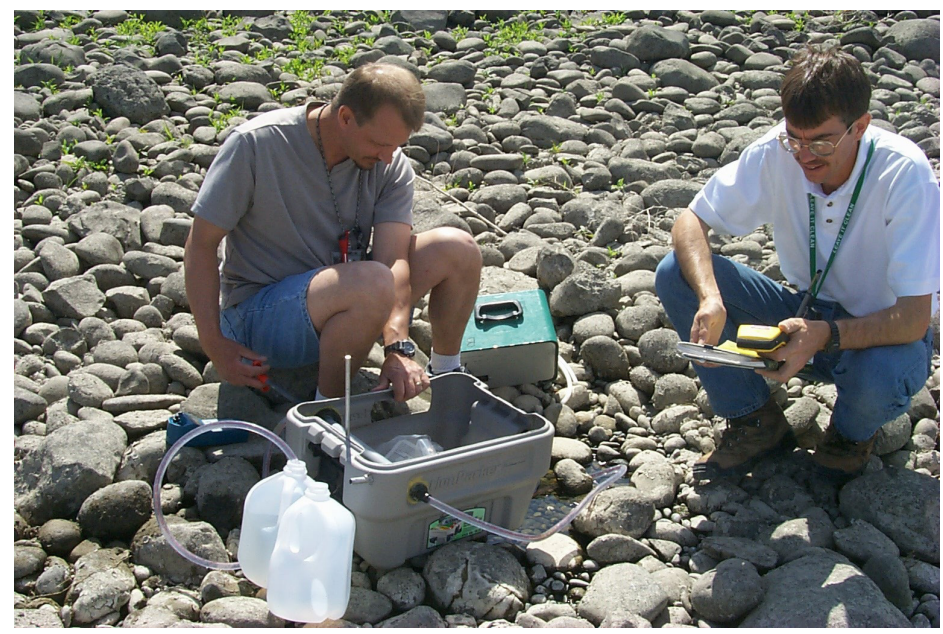

Routine monitoring of shoreline springs helps characterize the quality of groundwater discharging to the Columbia River and to assess the potential human and ecological risk associated with the spring water.
Samples of Columbia River shoreline spring water and sediment were collected along the Hanford Reach and analyzed for Hanford Site-associated radiological and chemical contaminants that are present in groundwater beneath the site.

Water from Columbia River Shoreline Springs. Samples of shoreline spring water were obtained from numerous locations in the fall of 2009 when Columbia River flows were low. Most samples were analyzed for gamma-emitting radionuclides, gross alpha, gross beta, and tritium. Samples from selected shoreline springs were analyzed for strontium-90, technetium-99, uranium-234, uranium-235, and uranium-238. Most samples were also analyzed for metals and anions, and samples from some locations were monitored for volatile organic compounds. All radiological contaminants measured in shoreline springs during 2009 were less than applicable DOE-derived concentration guides, but exceeded 
the Washington State ambient water quality criteria for gross alpha at some 300 Area locations and for tritium at the Hanford town site. In addition, uranium concentrations at some 300 Area locations exceeded the drinking water standard.

For most locations, the 2009 chemical sample results were similar to those previously reported. Concentrations of volatile organic compounds were near or below the analytical laboratory's required detection limits in all samples. Trace amounts of chlorinated organic compounds were observed at some locations. The concentrations of most metals measured in spring water samples in 2009 were below Washington State ambient surface water chronic toxicity levels. However, the maximum concentrations of dissolved chromium in water at some locations were above the Washington State ambient surface water chronic and acute toxicity levels. Concentrations of arsenic in all samples were below the Washington State ambient surface water chronic toxicity level, but exceeded the EPA limit for the protection of human health for the consumption of water and organisms. Arsenic, associated with historical application of arsenate on fruit orchards prior to World War II, has contributed to contamination on the Hanford Site.

Sediment from Columbia River Shoreline Springs. Shoreline springs sediment samples were collected at the 100-B, 100-H, 100-F Areas, the 300 Area, and the Hanford town site. In 2009, radionuclide concentrations were similar to concentrations measured in Columbia River sediment, with the exception of uranium concentrations in the 300 Area, which were above the concentration measured in sediment from the reservoir behind Priest Rapids Dam, upriver from the Hanford Site. Metals concentrations in all shoreline spring samples were similar to concentrations measured in Columbia River sediment samples.

\section{RADIOLOGICAL MONITORING OF HANFORD SITE DRINKING WATER}

Samples of treated drinking water were collected monthly at facilities in the $100-\mathrm{K}, 100-\mathrm{N}, 200-$ West, and 400 Areas. Water used in the 400 Area is pumped from wells. Water treated at other locations is obtained from the Columbia River. Water samples were analyzed for gross alpha, gross beta, tritium, and strontium-90. During 2009, annual average concentrations of all monitored radionuclides in Hanford Site drinking water were below federal and state maximum allowable contaminant levels.
Water sample results are compared to DOEderived concentration guides and Washington State ambient surface water quality criteria.

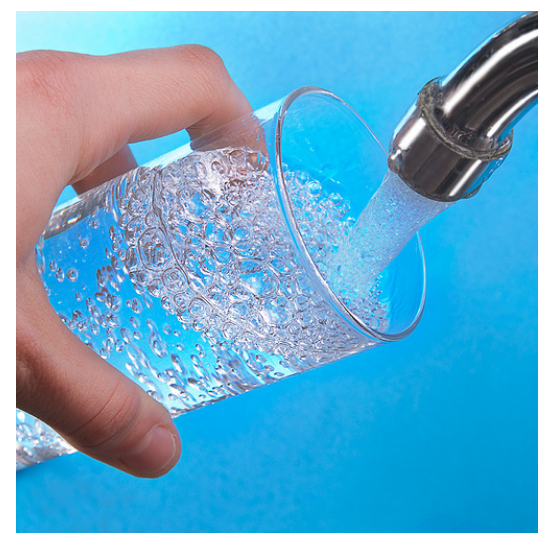

Drinking water is sampled at various locations on the Hanford Site. 


\section{GROUNDWATER MONITORING}

Liquid waste released to the ground at the Hanford Site during many years of nuclear materials production has reached the groundwater. Hazardous chemicals in the groundwater include carbon tetrachloride, chromium, and

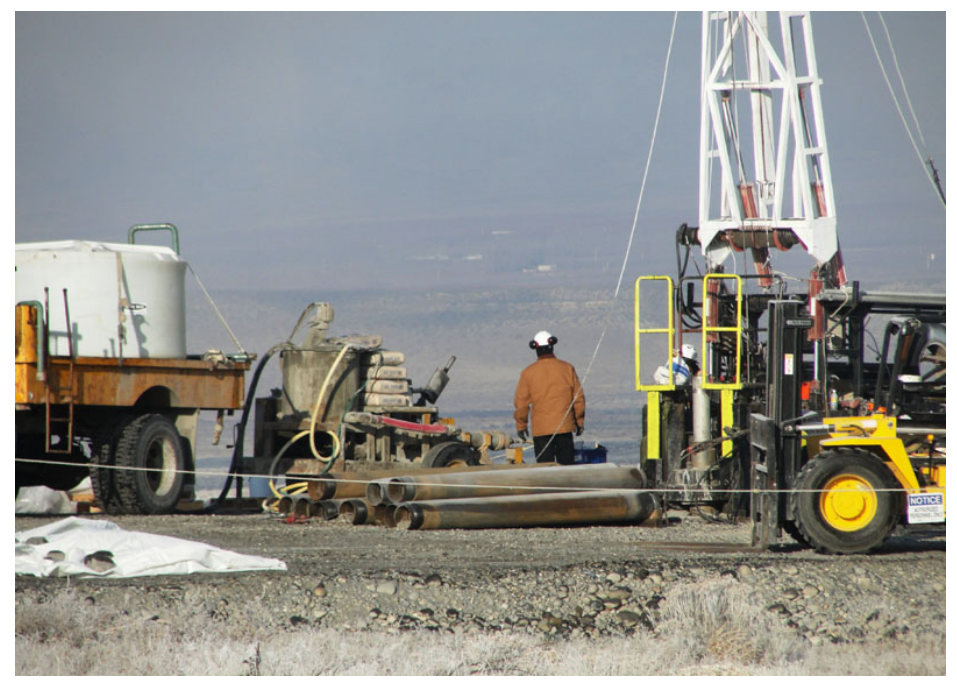

Fifty-two new groundwater monitoring wells were installed in 2009. Photo courtesy of the U.S. Department of Energy. cyanide. Radioactive contaminants include tritium, strontium-90, technetium-99, iodine-129, and uranium. Currently, groundwater contaminant levels are greater than drinking water standards beneath $11.3 \%$ (approximately 66 square miles) of the Hanford Site and are decreasing with time due to radioactive decay and contaminant dispersion. Site groundwater is not a source of public drinking water and does not significantly affect offsite drinking water sources, such as the Columbia River and city wells. However, there are possible nearshore effects where Hanford Site groundwater flows into the Columbia River. Groundwater monitoring and characterization continued in 2009, with the installation of 52 new monitoring wells and over 100 characterization boreholes. Further details are available in the Hanford Site Environmental Report for Calendar Year 2009 or the Hanford Site Groundwater Monitoring and Performance Report for 2009, available at http:// www.hanford.gov/rl/uploadfiles/GWRep09/start.htm.

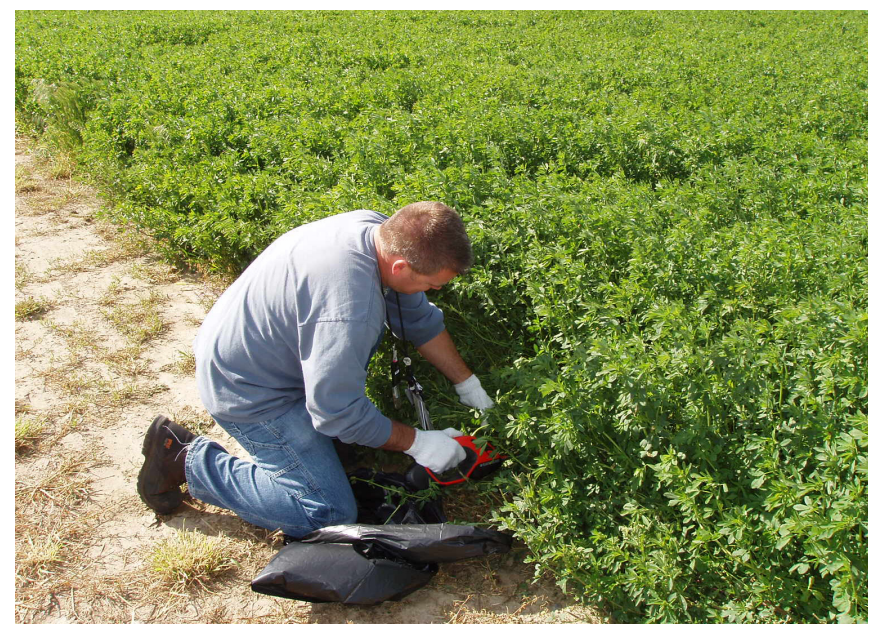

Alfalfa was sampled and analyzed for radiological contamination. Photo courtesy of Jeff Ferritto.

\section{FOOD AND FARM PRODUCTS MONITORING}

During 2009, food and farm products including alfalfa, apples, leafy vegetables, milk, potatoes, tomatoes, and wine were collected at places around the Hanford Site and analyzed for radiological contaminants. The concentrations of most radionuclides in food and farm product samples in 2009 were below levels that could be detected by the analytical laboratories. However, tritium and uranium-234 were detected in low levels in some samples, as was naturally occurring potassium- 40 . Concentrations were consistent with historical values. 


\section{SOIL MONITORING}

In 2009, soil samples were collected near facilities and operations at the Hanford Site to evaluate longterm trends in the environmental accumulation of radioactive materials, to detect the potential migration of contaminants, and to monitor the deposition of facility emissions. Samples were analyzed for radionuclides expected to occur in the areas sampled. In general, radionuclide concentrations in soil samples collected from or adjacent to operational areas and waste disposal facilities in 2009 were higher than the concentrations in samples collected farther away, and were higher than concentrations measured offsite in previous years. Generally, the predominant radionuclides detected were activation and fission products in the 100 Areas, fission products in the 200 and 600 Areas, and uranium in the 300 and 400 Areas.

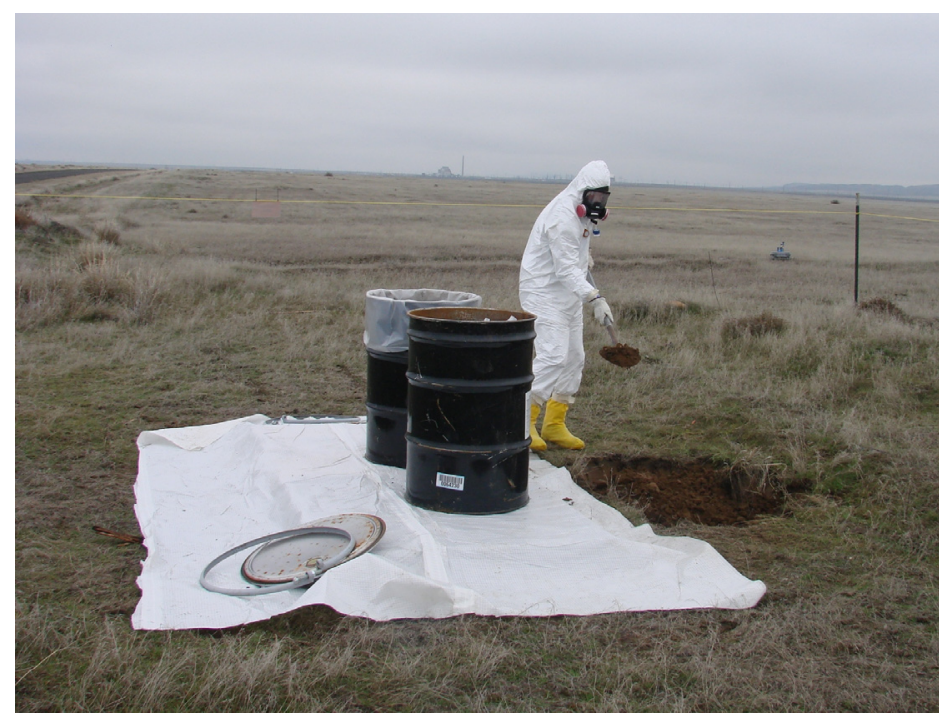

Soil monitoring is conducted near facilities and operations. Photo courtesy of Washington Closure Hanford, LLC.

\section{VEGETATION MONITORING}

Vegetation samples were collected on or adjacent to former waste disposal sites to monitor for radioactive contaminants. Samples were also collected from locations downwind and near or within the boundaries of operating facilities and remedial action sites. In general, radionuclide concentrations in vegetation samples collected from or adjacent to waste disposal facilities in 2009 were higher than concentrations in samples collected farther away, including concentrations measured offsite. Generally, the predominant radionuclides detected were activation and fission products in the 100-N Area, fission products in the 200 and 600 Areas, and uranium in the 300 and 400 Areas.

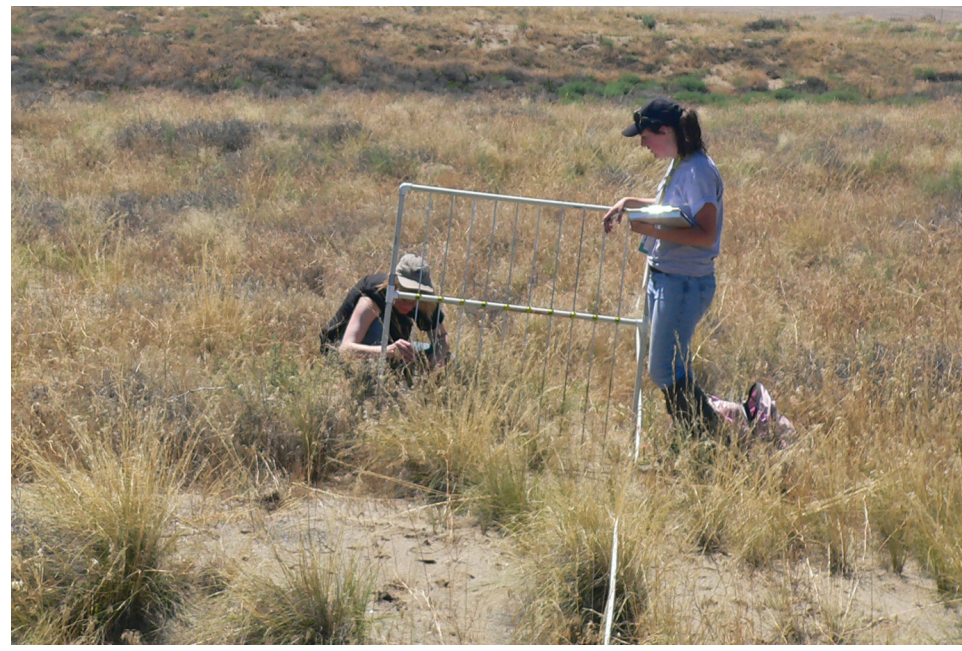

Vegetation is monitored from locations downwind and near or within operating facilities or remediation sites. Photo courtesy of Kyle Larson.

During 2009, radiological contamination was found in 109 vegetation samples collected around areas of known or suspected contamination or around specific project regions on the Hanford Site. One sample was rabbitbrush and 108 were tumbleweeds or tumbleweed fragments; all were disposed of at a licensed facility. 


\section{FISH AND WILDLIFE MONITORING}

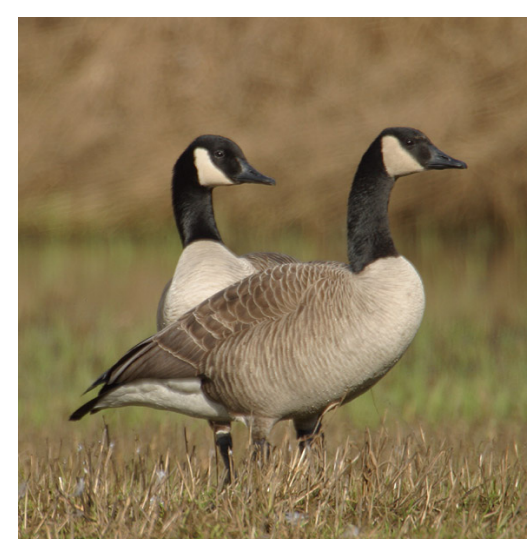

Canada geese were monitored for Hanford Site-produced contaminants.

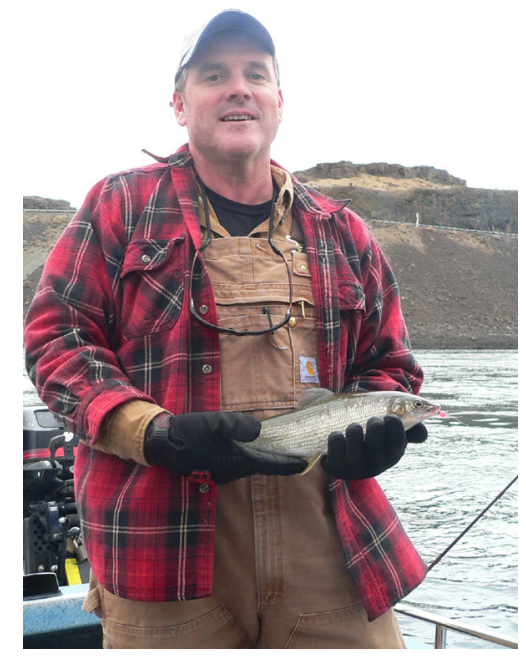

Whitefish were sampled in 2009 and analyzed for contaminants. Photo courtesy of Kyle Larson.
Fish and wildlife in the Hanford Site vicinity are monitored for site-produced contaminants. In 2009, Canada geese and whitefish were collected at locations on and around the site. Tissue samples were analyzed for strontium-90 and gamma emitters, including cesium-137. Since the 1990s, strontium-90 and cesium-137 have been the most frequently measured radionuclides in fish and wildlife samples. Cesium-137 was below detection limits in all samples in 2009. Strontium-90 was not found above the analytical detection limit in the whitefish samples collected during 2009, but was detected in two goose bone samples at levels similar to or less than values reported since 1999.

Liver tissues from most organisms were monitored for up to 17 trace metals that have the potential to accumulate in certain tissues and are potential contaminants of concern. Beryllium was not detected in any whitefish or goose samples. Maximum concentrations of aluminum, chromium, and mercury were higher in whitefish samples collected at Wanapum Dam than samples collected between 100-N and 100-D Areas during 2009. Maximum concentrations of the remaining 13 trace metals were higher in whitefish samples collected between the 100-N and 100-D Areas than maximum concentrations of samples collected from the background location. Antimony was not detected in any goose samples in 2009. Aluminum, arsenic, cadmium, lead, mercury, nickel, selenium, thallium, thorium, uranium, and zinc were elevated in goose samples collected in the Hanford Reach compared to concentrations of these metals detected in geese collected near Desert Aire, Washington, in 2009. Concentrations of chromium, manganese, and silver were elevated in samples collected near Desert Aire compared to samples collected in the Hanford Reach.

\section{EXTERNAL RADIATION MONITORING}

In 2009, external radiation on the Hanford Site was monitored onsite in relative close proximity to known, suspected, or potential radiation sources. A thermoluminescent dosimeter system is used to measure external radiation at the Hanford Site. Additionally, radiation surveys were conducted at some locations using portable instruments to monitor and detect contamination, providing for external radiation field screening.

Thermoluminescent Dosimeters. During the year, external radiation levels can vary from $15 \%$ to $25 \%$ at any location because of changes in soil moisture and snow cover, which can reduce or attenuate natural radiation intensity. During 2009, external radiation fields were monitored with thermoluminescent dosimeters at 119 locations near onsite facilities and operations. Measured radiation levels in the 100-K West Area, 100-N shoreline area, 
and the 200,300, and 400 Areas were similar to or lower than levels measured in 2008. Increased dose rate levels were observed in the 100-K Area (primarily K-East), 100-N Area, and at the Environmental Restoration Disposal Facility in 2009.

Radiation Surveys. In 2009, 560 radiation surveys were conducted at and around active and inactive waste disposal sites. During 2009, the Hanford Site had approximately 8,850 acres of outdoor contaminated areas of all types and approximately 1,430 acres that contained underground radioactive materials, not including active facilities. No new areas of significant size were discovered during 2009. Twenty acres that had been previously posted as contaminated or as areas containing radioactive materials were remediated and interim-closed.

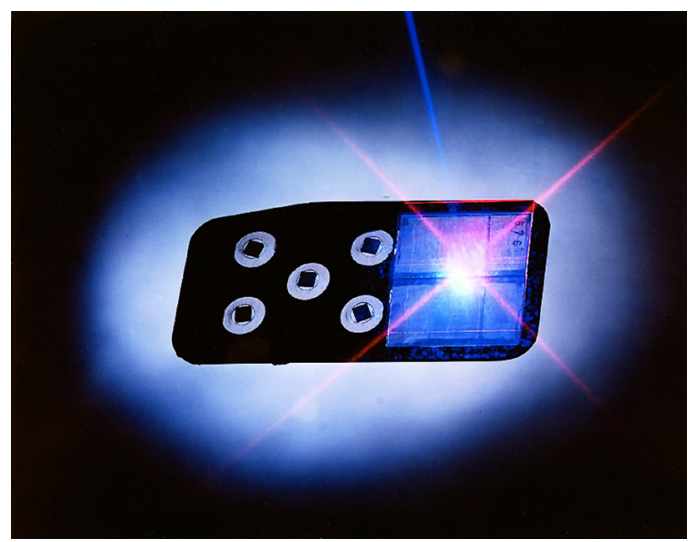

Thermoluminescent dosimeters are used to measure external radiation at the Hanford Site. In September 2009, aerial radiation surveys were conducted at the West Lake area and the BC Controlled Area.

\section{POTENTIAL RADIOLOGICAL DOSES FROM 2009 HANFORD SITE OPERATIONS}

During 2009, potential radiological doses to the public and biota from Hanford Site operations were evaluated to determine compliance with pertinent regulations and limits. Doses were assessed in terms of 1 ) total dose (multiple pathways) to the hypothetical, maximally exposed individual at an offsite location; 2) average dose to the collective population living within 50 miles of Hanford Site operating areas; 3) dose for air pathways using EPA methods; 4) dose to workers on the site consuming drinking water; 5) doses from non-DOE industrial sources on and near the Hanford Site; and 6) absorbed dose received by animals exposed to contaminants released to the Columbia River and in onsite surface water bodies. All doses from Hanford Site activities in 2009 were lower that EPA and DOE standards.

\section{NATURAL RESOURCES}

Plant populations are routinely surveyed on the Hanford Site. Rare or protected plant species are monitored, and contaminated or unwanted vegetation on the site is controlled.

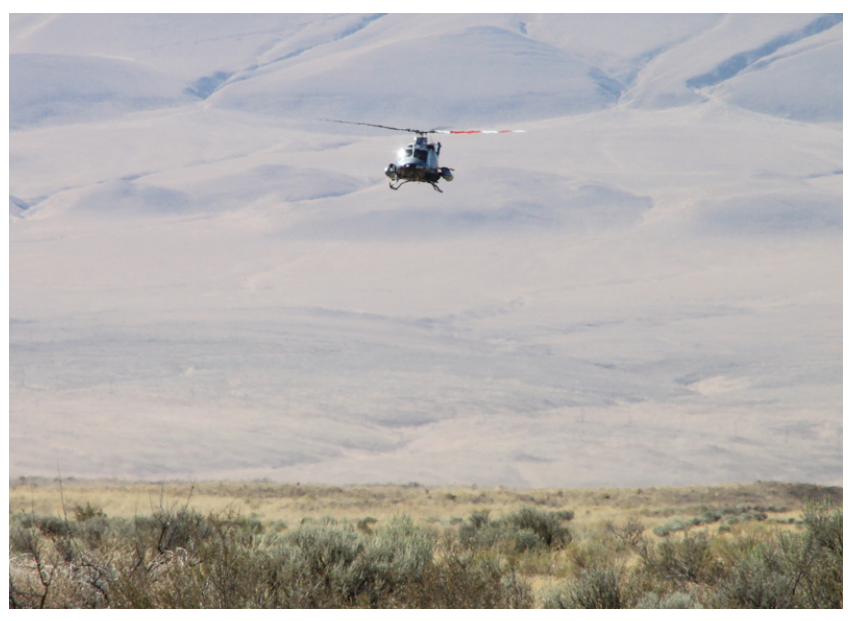

Aerial radiation surveys were conducted in 2009 to determine the extent of radioactive contamination in select Hanford Site areas. Photo courtesy of CH2M HILL Plateau Remediation Company.

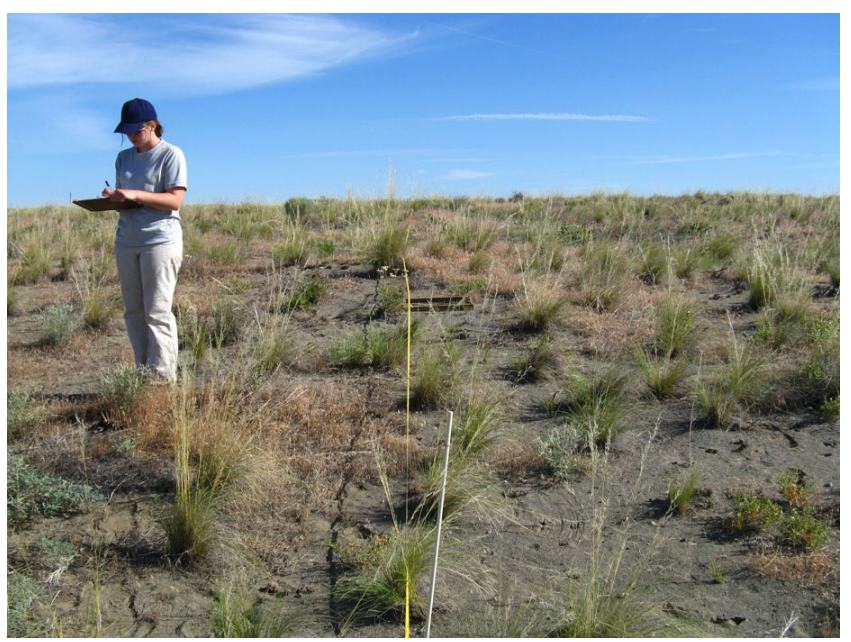

Plant populations monitored on the Hanford Site include Washington State listed endangered, threatened, sensitive, and candidate species. Photo courtesy of Chris Perry. 


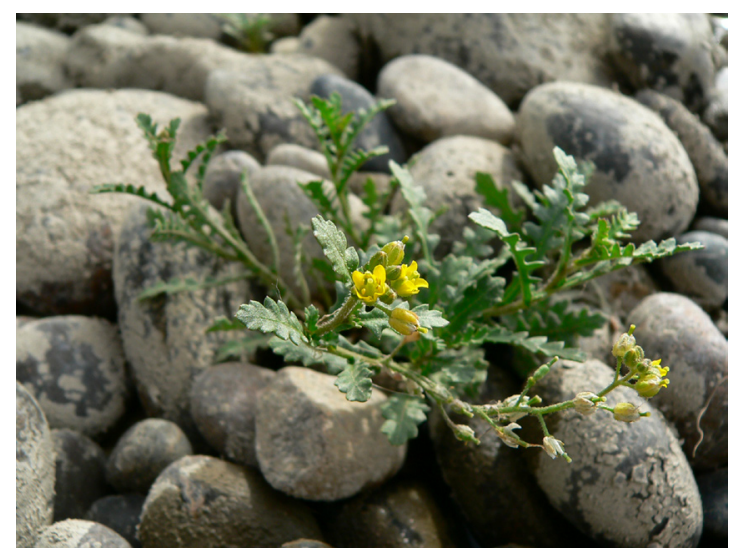

Columbia yellowcress, a federal species of concern and Washington State endangered species, was monitored in 2009. Photo courtesy of Kyle Larson.

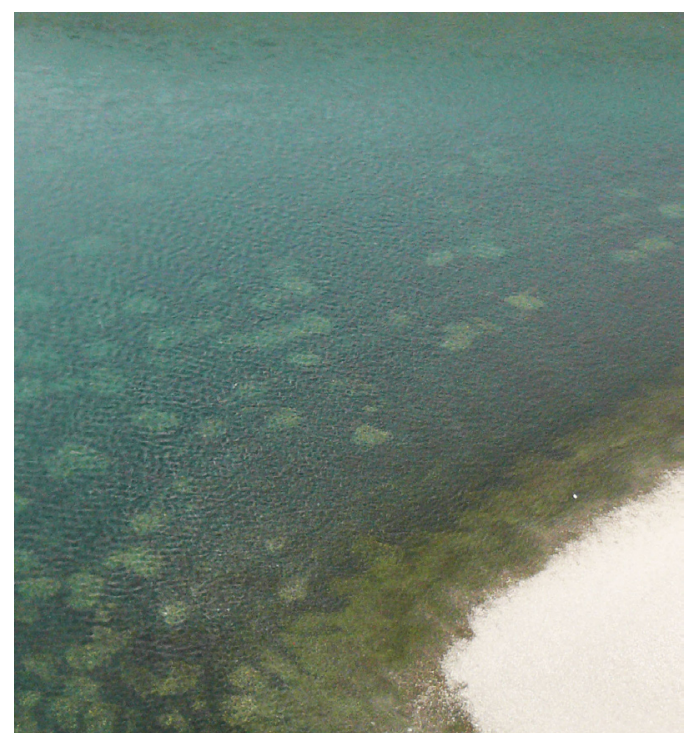

Salmon redds are estimated by aerial surveys. Photo courtesy of Robert Mueller.

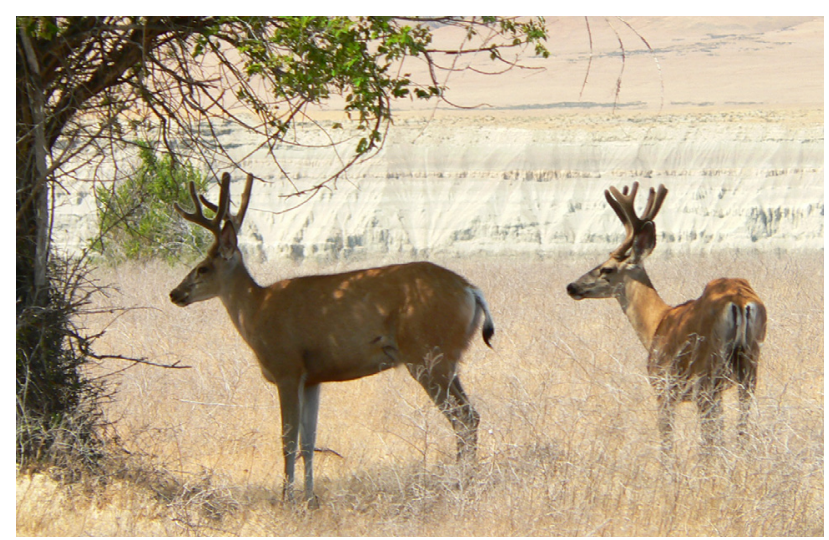

Mule deer are surveyed annually on the Hanford Site. Photo courtesy of Kyle Larson.
Plant Communities and Population Surveys. More than 100 plants found on the Hanford Site are listed by Washington State as endangered, threatened, sensitive, or on the review or watch list. In addition, six plants are species of concern or candidates for listing under the Endangered Species Act of 1973. Species monitored during 2009 include Umtanum buckwheat, a candidate for federal listing; and Columbia yellowcress, a federal species of concern. Both are Washington State endangered species.

Vegetation Control Activities. Vegetation control on the Hanford Site includes cleaning up contaminated plants that can be a threat to site workers or the public, controlling or preventing the growth or re-growth of plants in contaminated or potentially contaminated areas on the site, and monitoring and removing the 10 high-priority noxious plant species.

Wildlife Populations Surveys. Four fish and wildlife species on the Hanford Site are surveyed annually: fall Chinook salmon, steelhead, bald eagles, and mule deer. The number of fall Chinook salmon spawning nests (redds) in the Hanford Reach is estimated by aerial surveys. The peak redd count in the fall of 2009 was estimated at 4,995, lower than the 2008 count of 5,588, and 1,430 redds lower than the previous 5-year average. Two aerial surveys were conducted to identify possible steelhead spawning areas; none were found. Seventy-eight eagles (49 adults and 29 juveniles) were observed during 12 driving surveys in 2009. Roadside surveys were conducted for mule deer on the Hanford Site to assess age and sex ratios and the frequency of testicular atrophy in males. A total of 414 deer observations were made over 5 repeated surveys during November to mid-December 2009, which included multiple observations of the same animals in some cases.

In 2009, surveys were conducted to monitor breeding bird population abundance and habitat usage, and Rocky Mountain elk population abundance and movements. Nearly 120 species of birds have been observed on the Hanford Site in surveys conducted during the breeding season (April to June) from 1988 through 2009. Species abundance has declined from a high in 1989 of nearly 19 species per survey to approximately 7 species per survey in 2008 and 2009. The Rocky Mountain elk population in 2009 was estimated to be 677 elk. 
Habitat and Species Characterizations. Ecological monitoring on the Hanford Site includes the characterization of breeding locations, habitat use, and distribution of key wildlife species. In 2009, characterization studies focused on sampling plant communities subject to herbicide application and wildfires, and evaluating habitat features associated with burrowing owl nests. Two long-term monitoring plots established in 1996 that were aerially sprayed with herbicides in 2003 and 2006 were re-surveyed in 2009. Results indicate that native forb cover decreased significantly after herbicide treatment compared to forb cover measured in 2001 and 2002. A second survey compared data collected within areas previously treated with herbi-

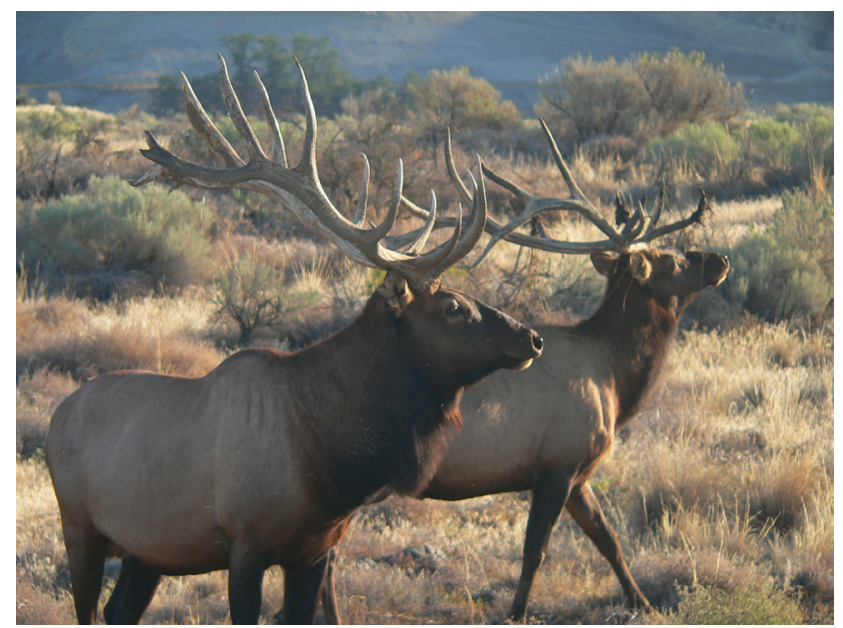

Rocky Mountain elk were surveyed in 2009. Hanford Site population was estimated to be 677 elk. Photo courtesy of Kyle Larson. the number of native forbs and canopy cover is lower in the treated areas. Regions of the Hanford Site burned by wildfires in 2007 were seeded with perennial bunchgrasses and forbs as protection from wind erosion. In 2009, preliminary surveys of vegetation in seeded and non-seeded areas showed that native grasses were recovering from the effects of wildfires; measures of exotic grass cover were approximately the same in seeded and unseeded areas. Burrowing owl habitat surveys in 2009 indicated that burrowing owls are less abundant on the Hanford Site than in nearby urban and agricultural areas. Nests are more common in sandy loam soils, and $71 \%$ of surveyed burrowing owl nests were located in abandoned badger burrows.

Control of Pests and Contaminated Biota. Animals (including insects) must be controlled when they become a nuisance, a potential health problem, or are contaminated with radioactivity. Biological control personnel responded to approximately 26,000 animal control requests from Hanford Site employees in 2009. There were 33 contaminated animals or animal-related materials discovered in 2009.

\section{CULTURAL AND HISTORIC RESOURCES}

DOE is responsible for managing and protecting Hanford Site cultural and historic resources. The Hanford Cultural and Historic Resources Program assists DOE in managing cultural and historic

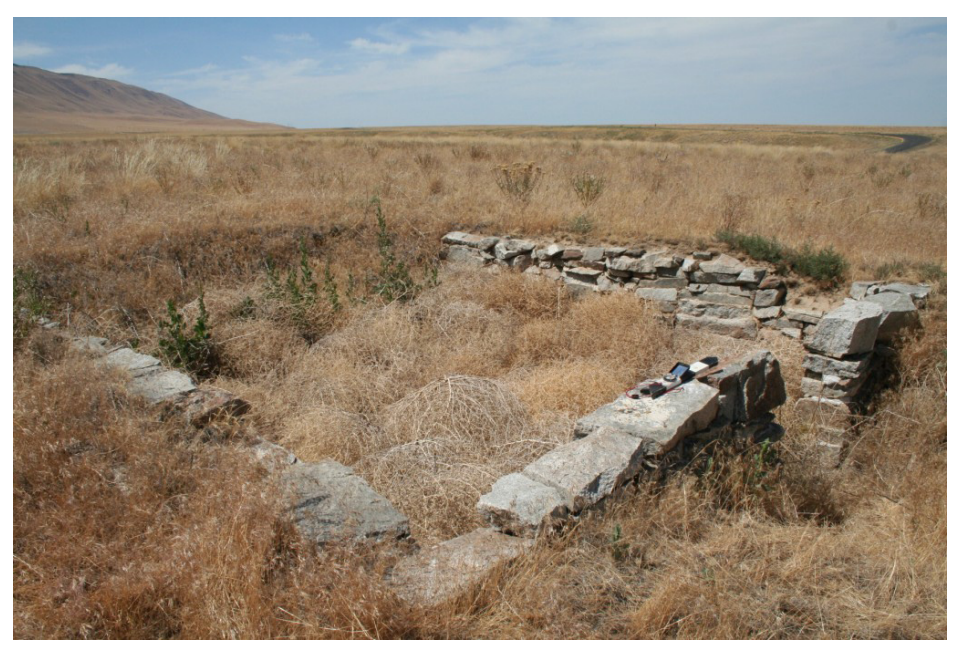

Remains of historic structures still remain on the Hanford Site. Photo courtesy of Doug McFarland. 


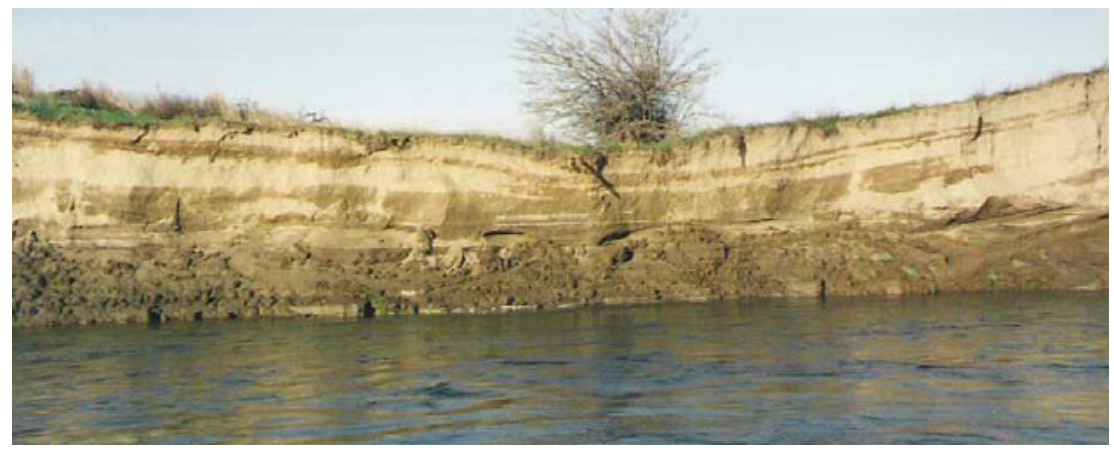

The effects of erosion and weathering on cultural resources are monitored annually. Shown is erosion at Locke Island. Photo courtesy of Bruce Bjornstad.

\section{Meteorological}

measurements are

taken to support

Hanford Site emergency

preparedness and

response, site

operations, and

atmospheric dispersion

calculations for dose

assessments.

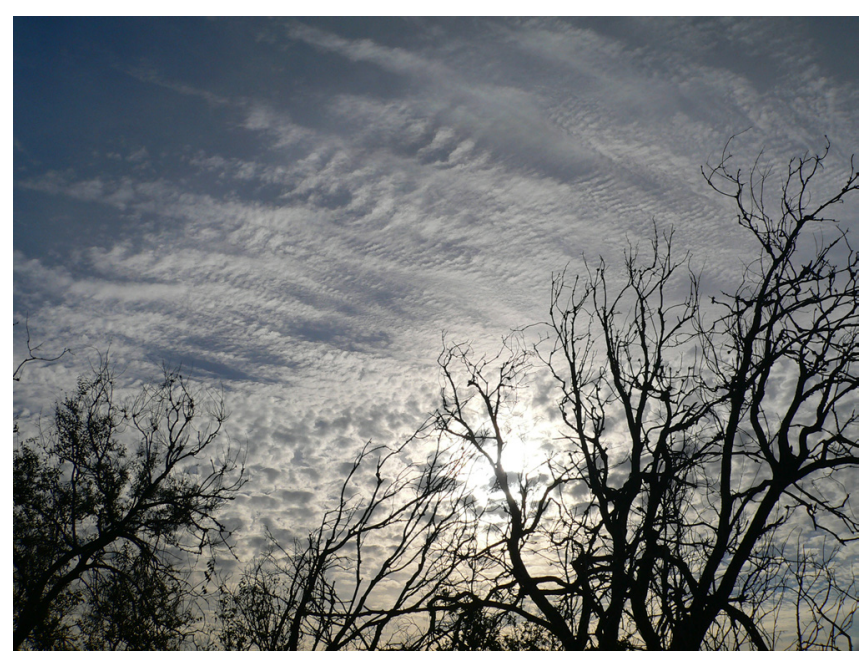

\section{CLIMATE AND METEOROLOGY}

Meteorological measurements support Hanford Site emergency preparedness, atmospheric dispersion calculations, worker safety, site cleanup planning and performance, and waste management operations. Activities include weather forecasting and maintaining and distributing climatological data.

The calendar year 2009 average temperature and precipitation totals were below normal. The average temperature for 2009 was $52.8^{\circ} \mathrm{F}$, which was $0.8^{\circ} \mathrm{F}$ below normal $\left(53.6^{\circ} \mathrm{F}\right)$. Six months during 2009 were warmer than normal and six months were cooler than normal.

Precipitation during 2009 totaled 5.47 inches, which is $78 \%$ of normal (6.98 inches). Snowfall for 2009 totaled 13.9 inches, compared to normal snowfall of 15.4 inches.

Weather conditions are monitored daily on the

Hanford Site. Photo courtesy of Kyle Larson. 
The average wind speed during 2009 was 7.8 miles per hour, which was 0.2 mile per hour above normal. The peak gust for the year was 61 miles per hour on March 15, 2009.

Four dust storms were recorded at the Hanford Meteorology Station during 2009, less than the five per year average for the entire period of record (1945-2009).

\section{QUALITY ASSURANCE}

Comprehensive quality assurance programs, which include various quality control practices and methods to verify data, are maintained by monitoring and surveillance projects to assure data quality. The programs are implemented through quality assurance plans designed to meet requirements of the American National Standards Institute, the American Society of Mechanical Engineers, and DOE Orders. Quality assurance plans are maintained for all activities, and auditors verify

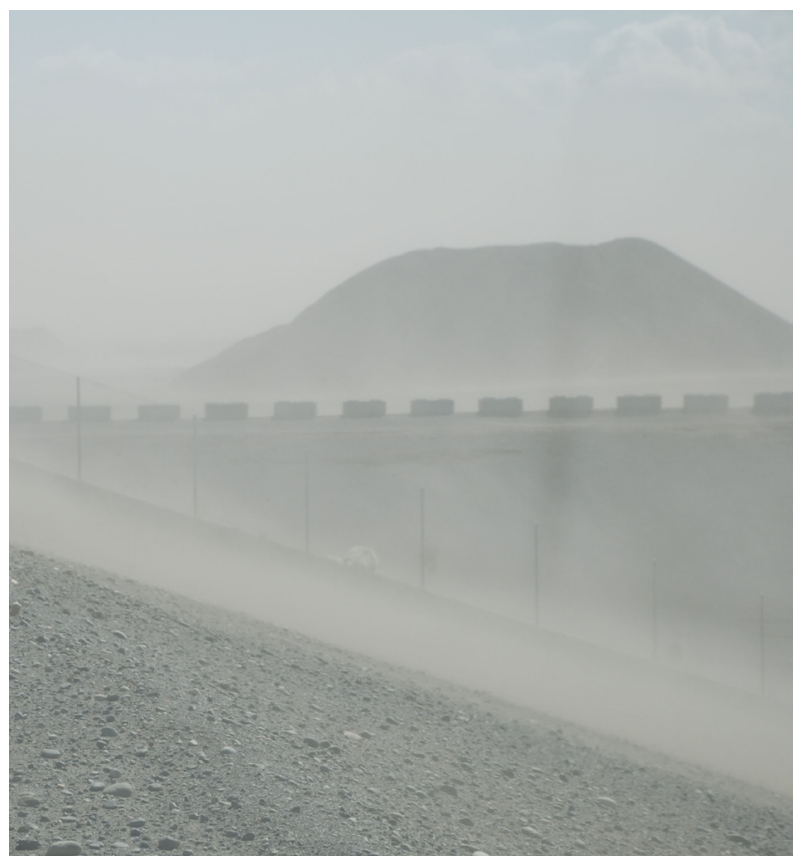

An average of five dust storms per year occur on the Hanford Site. Photo courtesy of Geoffrey Tyree, U.S. Department of Energy. conformance.

Samples are collected and analyzed according to documented standard procedures. Analytical data quality was verified by a continuing program of internal laboratory quality control, participation in interlaboratory cross-checks, replicate sampling and analysis, submittal of blind standard samples and blanks, and splitting samples with other laboratories.

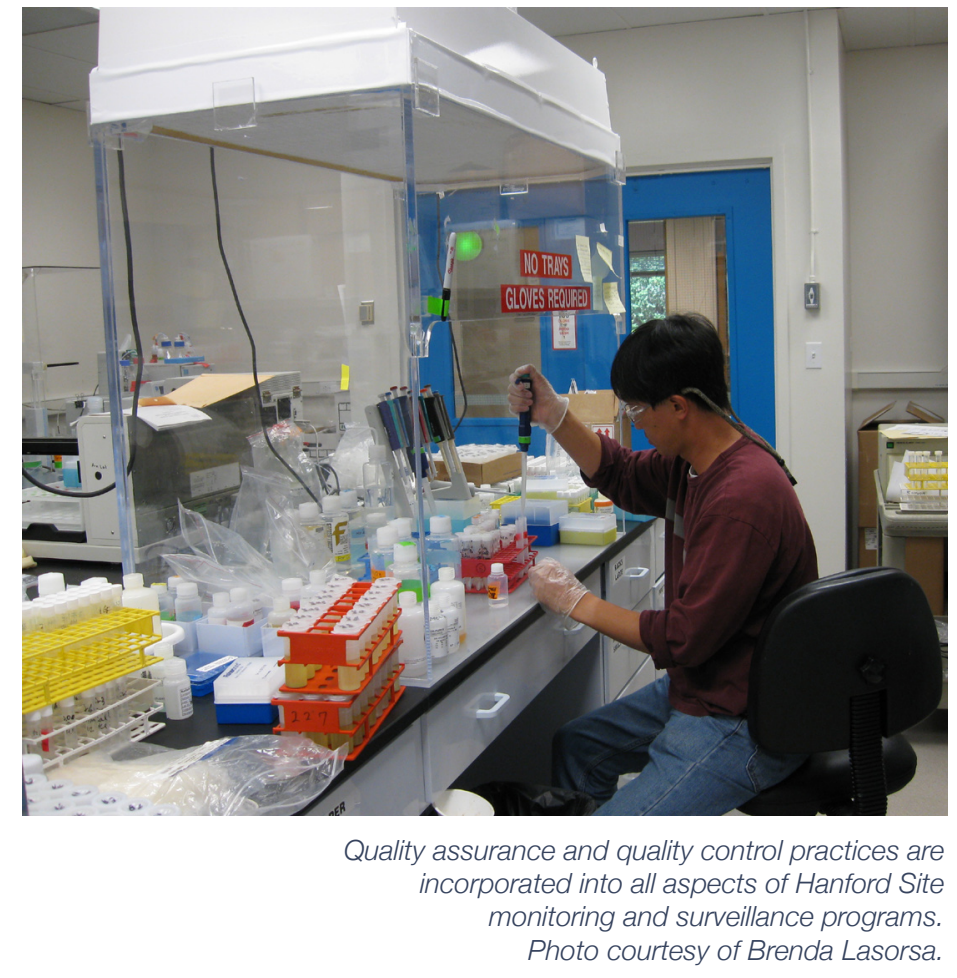




\section{REPORT INQUIRIES}

Inquiries about this booklet or comments and suggestions about its content may be directed to Mr. DC (Dana) Ward, U.S. Department of Energy, Richland Operations Office, P.O. Box 550, Richland, Washington 99352 (dana.ward@rl.doe.gov), or to Ms. JP (Joanne) Duncan, K6-85, Pacific Northwest National Laboratory, P.O. Box 999, Richland, Washington 99352 (joanne.duncan@pnl.gov).

Copies of this summary booklet and the 2009 environmental report have been provided to many public libraries in communities around the Hanford Site and to several university libraries in Washington and Oregon. Copies also can be found at the DOE's Public Reading Room located in the Consolidated Information Center, 2770 University Drive, Room 101L, in Richland, Washington. Copies of the 2009 report can be obtained from Ms. JP Duncan, K6-85, Pacific Northwest National Laboratory, P.O. Box 999, Richland, Washington 99352 (joanne.duncan@pnl.gov) while supplies last. Environmental reports can also be accessed on the Internet at http://hanford-site.pnl.gov/envreport. 
Prepared for the U.S. Department of Energy under Contract DE-AC05-76RL01830 by

(1) 